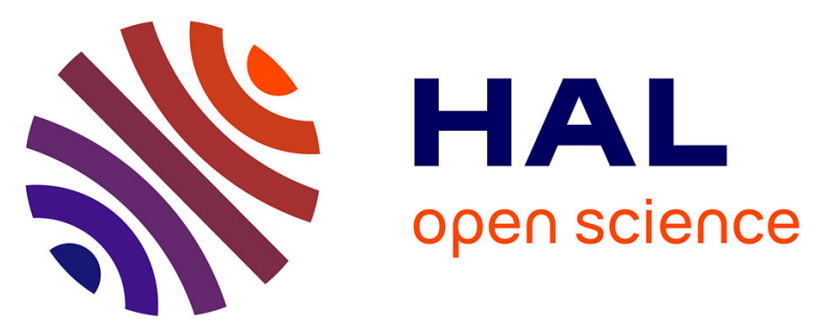

\title{
Adipose-Derived Mesenchymal Stem Cells in Autoimmune Disorders: State of the Art and Perspectives for Systemic Sclerosis
}

Alexandre At Maria, Maumus Marie, Alain Le Quellec, Christian Jorgensen, Daniele Noël, Philippe Guilpain

\section{To cite this version:}

Alexandre At Maria, Maumus Marie, Alain Le Quellec, Christian Jorgensen, Daniele Noël, et al.. Adipose-Derived Mesenchymal Stem Cells in Autoimmune Disorders: State of the Art and Perspectives for Systemic Sclerosis. Clinical Reviews in Allergy and Immunology, 2017, 52 (2), pp.234-259. 10.1007/s12016-016-8552-9 . inserm-01342436

\section{HAL Id: inserm-01342436 https://www.hal.inserm.fr/inserm-01342436}

Submitted on 6 Jul 2016

HAL is a multi-disciplinary open access archive for the deposit and dissemination of scientific research documents, whether they are published or not. The documents may come from teaching and research institutions in France or abroad, or from public or private research centers.
L'archive ouverte pluridisciplinaire HAL, est destinée au dépôt et à la diffusion de documents scientifiques de niveau recherche, publiés ou non, émanant des établissements d'enseignement et de recherche français ou étrangers, des laboratoires publics ou privés. 


\section{Adipose-derived mesenchymal stem cells in autoimmune disorders:}

perspectives for systemic sclerosis

Alexandre TJ Maria, MD ${ }^{1,2,3}$, Marie Maumus, $\mathrm{PhD}^{1,2}$, Alain Le Quellec, MD, $\mathrm{PhD}^{2,3}$, Christian Jorgensen, MD, PhD ${ }^{1,2,4}$, Danièle Noël, $\mathrm{PhD}^{1,2,4,{ }^{*}}$, Philippe Guilpain, MD, $\operatorname{PhD}^{1,2,3,{ }^{*}}$

${ }^{1}$ Inserm, U 1183, Saint-Eloi Hospital, 80 ave Augustin Fliche, Montpellier, F-34295

France; ${ }^{2}$ Montpellier University, Medical School, 2 rue de l'Ecole de Médecine, Montpellier, F-34967 France; ${ }^{3}$ Department of Internal Medicine, Multiorganic Diseases, Saint-Eloi Hospital, 80 ave Augustin Fliche, Montpellier, F-34295 France; ${ }^{4}$ Clinical Unit for Osteoarticular Diseases and Department for Biotherapy, Lapeyronie Hospital, ave du Doyen Giraud, Montpellier, F-34295 France. * equally contributing authors

Corresponding author: Daniele Noël, Inserm U 1183, Institute for Regenerative Medicine and Biotherapy (IRMB), Hôpital Saint-Eloi, 80 avenue Augustin Fliche, 34295 Montpellier cedex 5, France, Tel: 33 (0) 467330473 - Fax: 33 (0) 46733 0113 - E-mail: daniele.noel@inserm.fr 


\section{Table of contents}

1. Introduction

2. Definitions

3. Mechanisms of action

4. MSC tissue specificity

5. MSC-based therapy in autoimmune disorders - state of the art

6. First results and perspectives in systemic sclerosis

7. Conclusion 


\section{Abstract}

Mesenchymal stromal/stem cells (MSC) are non-haematopoietic multipotent progenitor cells, first described in bone marrow in the middle of last century. Since then, MSC have been the objects of a myriad of publications, progressively increasing our knowledge on their potentialities and bringing high expectancies for their regenerative properties. During the same period, numerous tissues, such as adipose tissue, placenta or umbilical cord, have been used as alternative sources of MSC in comparison with bone marrow. In particular, considering the accessibility and ease to harvest fat tissue, adipose-derived MSC have gained interest above bone marrow-derived MSC. More recently, the discovery of MSC immunomodulatory properties made MSC-based therapy progressively slip from the field of regenerative medicine to the one of autoimmunity. Indeed, in this group of disorders, caused by aberrant activation of the immune system resulting in loss of self-tolerance and autoreactivity, conventional immunosuppressant may be harmful. One advantage of MSC-based therapy would lie in their immune plasticity, resulting in space and time limited immunosuppression. More specifically, among autoimmune disorders, systemic sclerosis appears as a peculiar multifaceted disease, in which autoimmune phenomena coexist with vascular abnormalities and multi-visceral fibrosis. Considering the pleiotropic effects of MSC, displaying immunomodulatory, angiogenic and antifibrotic capabilities, MSC-based therapy could counteract the three main pathogenic axes of systemic sclerosis and might thus represent a complete breakthrough in this intractable disease with unmet medical need. In this article, while reviewing most recent literature on MSC biology, we itemize their current applications in the field of autoimmunity and shed light onto the potential use of adipose-derived MSC as an innovative strategy to cure systemic sclerosis. 


\section{Abbreviations used in the manuscript:}

a-SMA: alpha-smooth actin muscle

AID: autoimmune disorders

AOPP: Advanced Oxidation Protein

Products

ANCA: antineutrophil cytoplasm antibodies

ASC: adipose-derived mesenchymal stem cells

AT: Adipose tissue

ATMP: Advanced-Therapy Medicinal Product

bFGF: basic fibroblast growth factor

BILAG: British Isles Lupus Assessment Group

CD : Crohn's Disease

CFU-F: colony-forming unit-fibroblasts

CGH: Comparative Genomic

Hybridization

CIA: collagen induced arthritis

CNS: central nervous system

CXCR4: chemokine C-X-C motif receptor 4

$\mathrm{DC}$ : dendritic cells (mDC: mature, iDC: immature)

EAE: experimental acute encephalomyelitis

EC: endothelial cells

FDA: Food and Drug Administration

FISH: Fluorescence In Situ Hybridization

GFP: green fluorescent protein
GILZ: Glucocorticoid Induced Leucin Zipper

GM-CSF: Granulocyte Macrophage Stimulating Growth Factor

GMP: good manufacturing practices

GvHD: Graft versus Host Disease

HO-1: Heme Oxygenase 1

HOCl: hypochlorite

HSCT: hematopoietic stem cell transplantation

IA: intra-articular

IBD: Inflammatory bowel diseases

IDO: indoleamine 2,3 dioxygenase

IFN: interferon

Ig: immunoglobulin

IL: Interleukin

IL1-RA: Interleukin 1 Receptor Antagonist

iNOS: inducible NO synthase

IP: intra-peritoneal

iPSC: induced pluripotent stem cells

ISCT: International Society for Stem Cell Therapy

IT: intra-tracheal

IV: intravenous

LIF: Leukemia Inhibitory Factor

LPS: lipopolysaccharide

MHC: Major Histocompatibility complex

MMP: metalloprotease 
MOG: myelin oligodendrocyte glycoprotein

MPC: multipotent progenitor cells

mRSS: modified Rodnan skin score

MS: multiple sclerosis

MSC: mesenchymal stromal/stem cells

mMSC: murine MSC; hMSC: human

MSC; BM-MSC: bone-marrow derived mesenchymal stem cells; UC-MSC: umbilical cord MSC

NK: Natural Killer

OPG: osteoprotegerin

$\mathrm{PAH}$ : pulmonary arterial hypertension

PBMC: peripheral blood mononuclear cell

PD-1/PD-L1: programmed death-1/ programmed death ligand-1

PGE2: prostaglandin E2

PHA: phytohemagglutinin

PLP: proteolipid proteins

RA: Rheumatoid Arthritis
RANK/RANKL: Receptor Activator of Nuclear Factor Kappa-B / RANK Ligand

ROS: reactive oxygen species

SCID: Severe combined immunodeficiency

SCF: Stem Cell Factor

SDF-1: stromal cell derived factor-1

SLE: Systemic Lupus Erythematosus

SLEDAI: SLE Disease activity score

SRY: sex region of $Y$ chromosome

SSc: systemic sclerosis

SVF: stromal vascular fraction

TIMP: tissue inhibitor of metalloprotease

TNF: tumor necrosis factor

TNFR: tumor necrosis factor receptor

TSG-6: Tumor Necrosis Factor Inducible Gene 6

URC: ulcerative recto-colitis

VCAM: vascular cell adhesion molecule 


\section{INTRODUCTION}

Since the first description of mesenchymal stromal/stem cells (MSC) in the middle of last century, our knowledge has considerably increased and we can now expect to benefit from the regenerative properties of these cells in innovative therapeutic approaches. In the last decades, earlier studies focused on MSC differentiation capacities, but with discovery of their immunomodulatory properties, MSC-based therapy progressively slipped from the field of regenerative medicine to the one of autoimmunity. This rising interest in cell therapy using MSC for autoimmune disorders (AID) is conspicuous when looking at the number of original publications and review articles on the subject [1-4], as well as the growing number of clinical trials using MSC, among which one third concerns applications to autoimmune diseases (for the latest update, see http://www.clinicaltrials.gov). During the same period, adipose tissue emerged as a convenient source of MSC, and because of potent immunosuppressive abilities, adipose-derived mesenchymal stem cells (ASC) have gained interest above bone marrow derived mesenchymal stem cells (BM-MSC) in clinical trials. Still there remains questions regarding MSC applications in the clinic, in particular those related to the precise characterization of these cells according to tissue origin, but also regulatory issues concerning production and standardization of cell preparations for good manufacturing practices (GMP). This point is crucial considering the need for randomized controlled trials evaluating MSC in AID.

Among AID, systemic sclerosis (SSc) appears as a peculiar multifaceted disease, in which autoimmune phenomena coexist with vascular abnormalities and multivisceral fibrosis [5,6]. Considering immunomodulatory, angiogenic and antifibrotic capabilities of MSC, MSC-based therapy could represent a complete breakthrough in 
this severe life-threatening disease with unmet medical need [7]. In this article, while reviewing most recent literature on MSC biology and immunomodulatory capacities, we detail the current applications of MSC in the field of AID and shed light onto the potential use of ASC in SSc.

\section{MSC: DEFINITION}

\subsection{History and introduction of MSC in physiology}

MSC were first identified in the 1960's by Alexander Friedenstein [8], who isolated non-haematopoietic cells from bone-marrow aspirates and qualified them as colony-forming unit-fibroblasts (CFU-F) because of their adherence to plastic and their fibroblastic-like shape in monolayer culture. He and others consecutively demonstrated their role in the haematopoietic niche, as bystanders with homeostatic features through the secretion of anti-apoptotic molecules, but also as active supporters of haematopoiesis through the release of trophic and growth factors: Stem Cell Factor (SCF), Granulocyte Macrophage Stimulating Growth Factor (GMCSF), Interleukin-6 (IL-6), Leukemia Inhibitory Factor (LIF), etc... He also demonstrated their capacity to generate osteogenic progenitors and their role in bone regeneration. Later on, MSC were found in other mesenchymal tissues (see paragraph 4) and shown to participate in tissue maintenance and homeostasis through their differentiation into mature cells. Their implication in wound healing was also rapidly outlined, and they are now considered as sensors in case of tissue injury, interacting with endothelial cells and secreting chemo-attractants, with a specific role for pericytes [9]. Their activation might thus be the primum movens of tissue inflammation, while MSC also play an important role in inflammation resolution and tissue repair, surpassing the confined role of progenitors required for cell turn-over. 
Since their discovery in the sixties and the first clinical application by Lazarus et al. in 1995 [10], various methods have been used to isolate, characterize and culture MSC, resulting in some inconsistencies in the results obtained and in difficulties to compare studies. Indeed, no specific marker can define a MSC to date, and even the terminology used has been discussed, some researchers disputing the stemness of these cells, and preferring the use of "multipotent progenitor cells" (MPC). Altogether, these observations led the International Society for Stem Cell Therapy (ISCT) to draw guidelines in 2006, and bring a consensual definition of MSC.

\subsection{MSC definition}

According to the ISCT, the official terminology to refer to these cells should be "multipotent mesenchymal stromal cells", which can still be abbreviated as MSC [11]. At the same time, the society brought minimal criteria for defining MSC and standardizing further studies in the field [12]. These criteria are still applicable today, and define MSC according to 3 main features:

1. Plastic adherence in standard culture conditions,

2. Specific surface antigen pattern :

- expression (> 95\% of cells) of CD73, CD90, CD105,

- no expression ( $<2 \%$ of cells) of pan-leucocyte antigen CD45, of haematopoietic and endothelial progenitor marker CD34, of monocyte/macrophage antigens CD14 or CD11b, of B lymphocyte antigens CD79 or CD19, and of class II antigen HLA-DR, to exclude haematopoietic contamination,

3. Tri-lineage differentiation potential into adipocytes, osteoblasts or chondrocytes. These differentiation abilities are evaluated in vitro under 
defined culture conditions and are characterized by specific stainings respectively using Oil Red O, Alizarin Red S, and Alcian blue or Safranin O (or collagen II immunohistochemical staining) and up-regulation of markers specific for each differentiated cell type.

\subsection{Limitations to the ISCT definition}

The choice made by the ISCT not to retain the "stemness" of MSC may seem rationale since this term implies a self-renewal capacity, which is still under debate for these cells. However, the terminology routinely applied still remains "mesenchymal stem cells", as shown by the higher number of references using this term in pubmed (39311 vs 25510 for mesenchymal stromal cells and 2667 for multipotent stromal cells). Concerning the multipotency of MSC, some could argue that these cells are pluripotent since they have now been shown to differentiate into cell types from other embryonic layers [13]. However, the demonstrations were mostly made in vitro, in very specific conditions. Another limitation to the ISCT definition is that it mostly refers to human MSC (hMSC), but human ASC do express CD34 in naïve state and during the first days of in vitro expansion [14]. No consensus exists as well for murine MSC (mMSC), whose pattern of surface markers can vary depending on genetic background, with an admitted specific expression of CD29, CD44, CD73, CD105, CD106, and Sca-1 [15,11,16]. Conversely, HLA-DR expression, another exclusion criterion in ISCT definition, can be induced after MSC stimulation with interferon gamma (IFN-y) and basic fibroblast growth factor (bFGF). Importantly, phenotypical and functional differences have been observed between MSC isolated from different tissues. Altogether, these observations illustrate the need for developing new definitions based on functional assays, making possible a better 
characterization of MSC preparations. Such definitions could additionally be useful to work on standardized and homogenised populations of cells [17] [18].

\subsection{Regulatory concerns}

The growing interest in the therapeutic potentialities of MSC progressively raised regulatory issues, as a prerequisite for broader clinical applications. Indeed, MSC are easily isolated and expanded in culture in two to three weeks, and can be cryopreserved, allowing long-term storage. The development of new techniques for isolation and of bioreactors for cell expansion should allow sparing precious time and be more cost-effective, making possible the large-scale production of MSC. Concordantly, the number of MSC-based clinical trials is constantly increasing, from 227 in 2012 to 597 in 2016, with a majority of applications for tissue regeneration, but almost one third for immunomodulation, and a minority for haematopoietic restoration (see clinicaltrials.gov).

In this context, the need for clinical-grade MSC led to other debates and regulatory definitions. In particular, the standardization of isolation and culture procedures is critical, both for safety reasons but also in order to make studies comparable. These standards may concern: the technique for recovery, the enzymes used, the quality of medium, animal serum, bioreactors for culture and amplification, closed and aseptic systems. The safety controls have to include microbiological controls (from the donor for viral concerns, and in culture acquired bacterial contamination, such as mycoplasma), but also search for genetic instability, using techniques ranging from a raw karyotype, to Fluorescence In Situ Hybridization (FISH) or Comparative Genomic Hybridization (CGH) arrays. Eventually, functional assays, relevant to the application considered could improve MSC use in the clinic 
(for instance, in vitro assay for immunosuppression) [18] [16]. However, the current impediment to a standardization of procedures using MSC lies in the high variability of regulatory rules from one country to another, questioning the comparability of clinical studies [19]. For instance, the usage of MSC in USA must meet the Food and Drug Administration (FDA) definition and comply with GMP standards [20], whereas European countries define MSC as an Advanced-Therapy Medicinal Product (ATMP, regulation 1394/2007), which includes guidelines for authorization, supervision, technical requirements, product characteristics, and labelling [21]. Efforts are still to be made for more harmonization of procedures in the future.

\section{MSC BIOLOGY AND PHARMACOLOGY}

\subsection{Immunomodulation}

First shown in the beginning of the century [22,23], MSC immunosuppressive capacities are well described and constitute a huge body of data, subject of numerous reviews $[24,13,25,2,26-31]$. However, discordant mechanisms have been observed, according to tissue origin of cells, species [32], in vitro and/or in vivo conditions. This prompted ISCT to make a proposal in 2013 and define a goldstandard for inter-study analyses (culture conditions, priming of cells, etc.) [25].

In vitro usual demonstration of MSC immunosuppressive function is based on the capacity of MSC to reduce the proliferation of immune cells in co-culture, affecting both innate and adaptive immunity. In these experiments, immune cells (total splenocytes, peripheral blood mononuclear cell (PBMC), or purified populations of cells) undergo polyclonal or antigen specific activation, using phytohemagglutinin (PHA), lipopolysaccharides (LPS), CD3, or a specific antigen. The main mechanism is paracrine and depends on the secretion of soluble factors, since the effects are still 
appreciable when MSC and immune cells are separated by a semi-permeable membrane (transwell), or can be mainly reproduced by the sole supernatant of activated MSC. Cell contact however amplifies the process.

Concerning $T$ lymphocytes, the anti-proliferative effect observed is likely due to G0/G1 phase cell cycle arrest by inhibition of cyclin D2, resulting in a reversible quiescence of these cells, rather than apoptosis of T cells [13]. This leads to effector cell anergy, as testified by the secretory profile of these cells, with a decrease of the pro-inflammatory cytokines IFN- $\gamma$, TNF- $\alpha$, IL-17 and an increase of IL-10 and IL-4 (switch to Th2 and/or regulatory phenotype). The two main and well described soluble factors responsible for these effects are: 1) indoleamine 2,3 dioxygenase (IDO), an enzyme whose activation depletes the surrounding environment in the essential amino acid tryptophan, which is catabolized into kynurenine, leading to the accumulation of breakdown toxic products [33,34,29]; 2) inducible NO synthase (iNOS) activation, with NO release in the vicinity, resulting in cytotoxicity on numerous immune cells (i.e. T lymphocytes, NK) [13]. These two enzymatic activities have been considered as essential since their selective inhibition reverses the inhibitory effect of MSC on immune cell proliferation. They are species specific, IDO and iNOS being expressed in human or murine cells, respectively (see infra). Other secreted factors are involved but their inhibition does not completely abrogate MSC suppressive functions. Among them, prostaglandin E2 (PGE2) [35], IL-6 [36], TGF- $\beta 1$, Hepatocyte Growth Factor (HGF), Tumor Necrosis Factor Inducible Gene 6 (TSG-6), Heme Oxygenase 1 (HO-1), HLA-G5 [13], Interleukin 1 Receptor Antagonist (IL-1RA) [37], and soluble TNF-Receptor 1 [38] seem of particular interest. We also demonstrated the role of Glucocorticoid Induced Leucin Zipper (GILZ) in the mediation of MSC immunosuppression and induction of non-pathogenic Th17 cell 
subset [39]. As previously discussed, cell contact can amplify the suppressive response on Th17 cell function, for example through the programmed death-1/ programmed death ligand-1 (PD-1/PDL-1) pathway, as recently shown by our team [40].

In addition to their suppressive effect on effector T cells, MSC are able to induce the generation and expansion of CD4+CD25+Foxp3+ regulatory $\mathrm{T}$ cells, resulting in peripheral tolerance [13] [41]. MSC also affect, directly or indirectly, the proliferation and/or cytotoxicity of NK cells, via soluble factors (PGE2 and TGF $\beta 1$ ) [42]. Similar suppressive effects have also been shown against B lymphocytes, both through the inhibition of proliferation and preventing the maturation of these cells towards plasmocytes, resulting in decreased production of immunoglobulins (lg) [43]. This effect on B cells could be indirect, resulting from MSC inhibition of activated Tcells [44]. Finally, MSC promote the maturation of antigen-presenting cells toward a regulatory phenotype. In particular, MSC suppress the differentiation of monocytes into mature dendritic cells (mDC) through IL-6 [45], IL-4 and GM-CSF secretion, resulting in the persistence of inhibitory immature (i)DC, with regulatory phenotype and induce the shift towards an anti-inflammatory M2-like phenotype [46,47].Few studies have reported their impact on neutrophils, yet indirect mechanisms can lead to the inhibition of neutrophil oxidative burst. This inhibition mainly occurs through the secretion of IL-10 by M2 macrophages, induced by the production of PGE2 and IL-6 by MSC [35].

Of note, the priming of MSC is required for most of these immunosuppressive effects. Indeed, resting MSC do not constitutively secrete high levels of the abovementioned factors and need activation by the surrounding inflammatory environment to polarize them towards a suppressive phenotype [48]. The main 
activators of MSC are IFN- $-\gamma$, TNF- $\alpha$ and, to a lesser extent IL-1 [25], More recently, the segregation between a MSC1 and a MSC2 phenotype, with pro-inflammatory and anti-inflammatory profiles respectively, has been described [26]. Although challenged, the description of these two phenotypes according to environmental stimuli could support the critical role played by MSC in immune homeostasis, in particular at the time of tissue injury. On the whole, convincing data demonstrate the broad spectrum of immunomodulatory effects of MSC towards innate and adaptive immunity. .

\subsection{Differentiation potential}

Besides adipocytes, osteoblasts and chondrocytes, MSC differentiate in vitro, upon specific culture conditions (i.e. hypoxia, 3D culture using biomaterial scaffolds, specific growth factors), into other mesodermal cells (myocytes, tendinocytes, cardiomyocytes), but also cells from endoderm (pneumocytes, hepatocytes, pancreatic islet beta cells), or ectoderm (epithelial cells, neuroglial cells, etc.) [49] [50]. In vivo, in lung injury, MSC ability to differentiate into alveolar epithelial cells may give credit to their regenerative potential $[51,52]$. However, the low frequency of MSC trans-differentiation doesn't seem meaningful in therapy [53], since most of the studies show poor engraftment of cells [54] or differentiation in vivo [55]. Anyhow, the regenerative properties of MSC have been demonstrated in various degenerative conditions such as myocardial infarction, stroke, and neurodegenerative disorders [56]. In osteo-articular diseases, bone or cartilage repair through tissue engineering or scaffold-free MSC-based therapies is evaluated in the clinics [57-65] (for review, see [66]).

\subsection{Trophic potential}


The trophic role of MSC, first described in the bone-marrow haematopoietic niche, is now highlighted in view of multiple applications in many disorders and is mostly based on the secretion of anti-apoptotic factors, proliferative and growth factors, angiogenic factors, and many others. The importance of MSC secretion has been demonstrated in bone remodelling through the modulation of Receptor Activator of Nuclear Factor Kappa-B Ligand (RANKL) and osteoprotegerin (OPG), but also in neuroprotection, cardiac regeneration, and generally in tissue remodelling [4] [67]. Beside anti-apoptotic and angiogenics properties, MSC prevent fibrosis through the secretion of HGF, metalloproteases (MMP), and the down-regulation of collagen synthesis [67]. Finally, anti-oxidative effects are also to be mentioned, through paracrine secretion or cell-contact. Most of these effects depend on paracrine secretion in the vicinity of target cells, but the role played by the extracellular vesicles (microparticles or exosomes) released by MSC seems to be key. Extracellular vesicles containing proteins, mRNAs and micro-RNAs, are now supposed to mediate most of the endocrine effects, apart from the site of MSC presence [67].

\subsection{In vivo fate of injected MSC}

\subsubsection{Biodistribution and pharmacology}

Various techniques have been used to track MSC following their administration, such as in vivo imaging using bioluminescence (luciferase) or fluorescent tracking (GFP), or molecular biology using quantitative PCR, allowing the tracking of male MSC infused into female mice using SRY gene amplification for instance. However, these techniques lack sensitivity while Alu-sequences tracking of hMSC infused into animals by GPCR has been shown to be far more sensitive. Considering the human-species specificity of Alu sequences and the high number of 
repetitions of these short interspersed elements on the genome, this technique displays a higher sensitivity and allows detecting one single hMSC among 100,000 murine cells $[68,69]$. These studies revealed that a majority of MSC was detected in lungs within 15 minutes following intravenous (IV) infusion, while only trace amounts could be found in circulation or in other tissues (i.e. liver, spleen, brain, or heart) [70,68] [71] [72]. Indeed, for rheological reasons as well as receptor-mediated chemo-attraction, IV-infused MSC are mostly trapped in lung vasculature [73]. More importantly, MSC do not persist in lungs more than a couple of days, even in syngeneic conditions or using SCID mice to avoid immune rejection of MHC unmatched cells [31]. Interestingly, biodistribution of cells may be affected by pathological conditions, with a preferential homing to injured parts of the lungs in case of acute lung injury, or even an extra-pulmonary migration to injured tissues [52].

Thus, the role of pro-inflammatory environment and more precisely of chemokines such as stromal cell derived factor-1 (SDF-1) or its receptor chemokine C-X-C motif receptor 4 (CXCR4) seem crucial in the process [74]. The migration through blood vessels also implies crossing endothelium and thus MSC expression of adhesion molecules such as vascular cell adhesion molecule (VCAM) [31]. Neither the presence of cells nor their persistence in tissues seem necessary for MSC longlasting benefits, and this argues for a "hit and run" mechanism of action, mostly based on paracrine secretion of molecules or extracellular vesicles [31] [67]. Of note, the route of administration can affect the kinetics of MSC distribution, with liver as the main target using intra-peritoneal (IP) infusion. In case of local intra-articular (IA) injection of high amounts of hASC into SCID mice, a long-term persistence could be observed ( $15 \%$ of cells the first month and $1,5 \%$ after six months), with a significant 
redistribution to the classical stem cell niches (bone-marrow, adipose tissue and muscle) [69].

Beside the route of administration, another pharmacological issue concerns the "dose" to be administered, namely the number of MSC to be injected. Few dose escalation studies have been published and positive dose-related effects were usually observed $[75,76]$. Conversely, other authors and our group have reported inverse dose effects using MSC [56,77,78] [70]. These inconsistent results can be explained by distinct sources of MSC, variable pathological environment, route and time of injection. Another explanation to these inverse dose-effects can be related to an increased probability of microembolia and MSC lung entrapment after infusing highest doses of MSC. Cumulatively, as claimed by Murphy et al [78], "more is not always better, and the effective doses must be determined based on the clinical application".

\subsubsection{Immunogenicity of MSC}

MSC have long been considered as immune privileged since they display no or low expression of class I MHC and of co-stimulatory molecules (CD40, CD80/CD86) [79] and do not induce potent allo-reactivity when infused into another organism [31]. Nonetheless, in contradiction to what had been initially thought, they do not completely escape immune surveillance, since they can be recognized and cleared by NK cells [80]. In addition, they have been shown to elicit cellular and humoral responses in vivo $[81,31,82]$, sometimes in association with a lack of effect [83]. However, according to the proposed "hit and run mechanism" of action, immune rejection appears to not preclude their efficacy at least on the short- or middle-term $[31,54]$. As a whole, MSC transplantation across MHC barriers seems possible and 
probably as effective. Still, the question of autologous or allogeneic condition has to be taken into consideration in the design of clinical trials using MSC in Humans.

\subsubsection{Safety}

Even if we have hindsight on safety considering the wide-scale use of MSC in the last decade, MSC-biotherapy still raises some questions, and some of them remain unanswered. The first issue concerns the possible ectopic tissue formation using multipotent progenitors that possess ability to differentiate. As said earlier, these abilities have rarely been shown in vivo, where only a low amount of MSC remains, with no long-term engraftment. Although heart calcifications have been reported [84], ectopic tissue formation after MSC infusion is assumed very unlikely. Second, contrary to induced pluripotent cells (iPSC) or embryonic stem cells, MSC are not associated with a risk of teratoma formation, because they are adult stem cells with restricted potential of differentiation. The third issue concerns the oncogenic risk of such a biotherapy $[85,86]$. Indeed, genetic instability has been noted in culture [87], but was associated to extended time in culture and high passages. Reassuringly, no immortalization of hMSC was noted in culture, and karyotype abnormalities did not lead to the emergence of oncogenes. If sarcoma transformation has been suspected once [88], the majority of studies did not show any malignant transformation of cells in the short and middle terms [89] [90]. In fact, early studies have been retracted due to MSC contamination by tumor cells during cultures. Eventually, caution should be exercised using MSC in patients with past history of cancer, since MSC immunosuppression may limit antitumor immunity and consequently favour tumour growth $[48,91]$. On the whole, based on a recent meta-analysis gathering more than 1000 patients, the only adverse event significantly associated to MSC treatment was 
transient fever at the time of infusion [92]. No association with acute toxicity, organ system complications, infection, malignancy or death was to be noted.

\section{TISSUE ORIGIN OF MSC}

\subsection{Sources}

First isolated from bone marrow (BM), MSC have been described in numerous adult tissues such as periosteum, perichondrium, synovium, muscle, adipose tissue (AT), dental pulp, lymphoid tissues, and virtually all tissues may contain MSC in various proportions [93,94] [95]. Other potential sources are menses [96] and fetal or neonate annexes such as placenta, amniotic membrane, umbilical cord (UC) blood or Wharton jelly [97]. Undoubtedly, BM being the most described source of MSC, BMMSC are a reference in all studies. However, isolation from BM encounters limitations, such as the invasive and potentially painful procedure for the donor, and the low number of progenitors harvested due to the rarity of MSC within this tissue $(1 / 100,000)$. For these reasons, the possibility to harvest MSC from other tissues was developed.

\subsection{Between-sources comparison}

Whatever the tissue they originate from, MSC meeting the ISCT minimal criteria should share common biological features. However, tissue specificity has been suggested, and concerns MSC phenotype (i.e. CD34+ for ASC, CD270+ for amnion MSC), expression profile and functionality [95,98] [99] [100] [101] [102]. For these reasons, the concept of a unique MSC is controversial [103]. Because of higher proliferative rate and stronger inhibition of T-cell proliferation, ASC are very promising [104] [105] [106-108]. 
Considering the accessibility and ease to harvest adipose tissue, an increasing number of studies are using ASC rather than BM-MSC [109]. In practice, the medical procedures used (lipectomy or simple lipoaspiration) are associated with very low donor morbidity, and a high available volume of tissue. Once adipose tissue collected, collagenase digestion and centrifugation separates stromal vascular fraction (SVF) from fat and blood fluids. Among other mature cells and progenitors, this SVF contains ASC in a variable proportion reaching $2-10 \%$ of cells with CFU-F capacity, which represents up to a 10,000 fold increased yield compared with BM-MSC isolation [110]. In this context, companies have gambled on the potential of adipose tissue and developed cell separation systems that allow immediate isolation and separation in the operating room [111]. Hence, ASC-containing SVF can be delivered to the patient in the very same procedure, if autologous and orthotopic approach is applicable. However such procedures do not isolate ASC and therefore lead to the implantation of endothelial cells as well as different immune cell types, which can potentially be inflammatory.

Concerning the phenotype and functions of ASC, we already noted that naïve ASC express CD34, although in contradiction with ISCT criteria for MSC. In fact, expression of this marker is lost during ex vivo culture when cells proliferate. Besides, ASC phenotype is well described [112] [113] [114]. Recently, our team evaluated two different techniques for harvesting AT: traditional manual lipoaspirate using a cannula and a syringe vs water-jet assisted aspiration (Bodyjet $\circledast$ ), a device allowing good esthetical results, together with better tissue protection, increased cell viability and lower cardiovascular adverse events for the donor. In this study, we did not show a significant impact of the technique in terms of SVF/ASC characteristics at isolation, and of in vitro and in vivo immunosuppressive functions [115]. Regarding functionality, 
many studies agree to qualify ASC as the strongest immunosuppressors compared to MSC from other sources (including BM-MSC) [106-108] [116] [117], both through a stronger inhibition of activated B cells and Ig production, and a greater impact on monocyte-DC differentiation and maturation. Furthermore, ASC may display more proangiogenic, antiapoptotic and antioxidant capacities [118] [119] [120]. All in all, adipose tissue represents one of the best sources of adult mesenchymal stromal progenitors, and ASC stand as ideal candidates for MSC-based clinical applications.

\section{MSC-BASED THERAPY IN AUTOIMMUNE DISEASES - STATE OF THE ART}

\subsection{General points}

AID is a group of disorders caused by a dysfunction of the immune system, resulting in a break of self-tolerance and auto-reactivity. On the one hand, organ specific AID, such as autoimmune thyroiditis or type 1 diabetes, can lead to monoorganic failure, and may require long term substitutive therapy or organ transplantation; on the other hand, systemic AID, notably Systemic Lupus Erythematosus (SLE) or Systemic Sclerosis (SSc), whose features can be highly variable, may require immunosuppressive therapy. Actual immunosuppressant expose patients to loss of protective immune response against infectious agents (i.e. bacteria, viruses, fungi or parasites) or tumour development. These opportunistic infections are as frequent using target therapies as using conventional immunosuppressants [121]. One advantage of MSC-based therapy would lie in the specificity of the response according to the pathological environment, resulting in local and time-limited immunosuppression. Interestingly, alterations of resident MSC have been reported in various AID including SLE, Rheumatoid Arthritis (RA) and SSc, resulting in premature senescence of cells and impaired functionality, in particular in 
terms of immunosuppression [122] [123] [124-126]. The question remains whether these alterations are a consequence of the pathological environment or the primum movens of AID pathogenesis.

Indeed, because MSC are involved in immune peripheral tolerance (for instance suppressing T cell reactivity), primary alteration in MSC niche could impair immune homeostasis and generate auto-reactivity. In that context, beside direct immunosuppressive benefits, allogeneic MSC administration could help counteract the process in the niche and restore healthy resident MSC phenotype through the supply of trophic factors. The first demonstrations of MSC-associated immune tolerance were made in animal models of allografts, where syngeneic MSC were able to decrease immune rejection of MHC unmatched cells or tissues [127], for review see [13]. Moreover, our team reported that MSC administration allowed allogeneic tumour growth in vivo [48]. Numerous studies thereafter demonstrated the immunosuppressive properties of MSC in animal models of auto-immunity, first in experimental acute encephalomyelitis (EAE), a murine model for multiple sclerosis [128], in collagen induced arthritis (CIA), a murine model for rheumatoid arthritis [129] [130], in genetic models of murine lupus [131], in Graft versus Host Disease (GvHD) [132], or autoimmune type 1 diabetes [133]. The possibility to prime in vitro of MSC before injection could amplify their immunosuppressive function as reported in GvHD [134]. Therefore, the question of route of administration, source of cells and the possibility of autologous approach has to be raised in each case.

\subsection{Systemic Lupus Erythematosus (SLE)}

SLE is a heterogeneous multi-systemic AID affecting young women and displaying variable clinical features, from cutaneo-articular to systemic life- 
threatening manifestations with kidney, heart or central nervous system (CNS) involved [135-137] [138] [139] [140] [141,142] [143]. While B cell activation is pivotal in SLE pathogenesis and associated with the production of anti-double strain DNA auto-antibodies (anti-dsDNA Ab) [144], impaired clearance of apoptotic bodies and defective regulatory $T$ cells are also involved [145]. SLE often requires long-term conventional immunosuppression, in particular corticosteroids, cyclophosphamide, or mycophenolate mofetil, and is not devoid of metabolic and infectious adverse effects associated with reduced life span [146-149] [150]. Recent specific therapies targeting B lymphocytes (i.e. rituximab through CD20), T/B cooperation (co-stimulatory molecules), or BAFF (belimumab, anti-Blys monoclonal antibody) failed to improve significantly the overall prognosis of this disease [151] [152] [153] [121]. Thus, through their immunomodulatory properties, MSC could help extend the therapeutic arsenal in refractory cases of SLE, as well as reducing long-term exposure of patients to steroids and other immunosuppressants [154] [7].

Regarding MSC from SLE patients, studies have reported alterations in their haematopoietic support function [155], and osteogenesis capacity [156]. Moreover, MSC from SLE patients display senescent features such as large cells with low proliferation rate [122,157], alterations in gene expression [158] and cell cycle through p16ink4A, ERK1 and wnt/beta-catenin pathways modulation $[159,160]$. Increased apoptosis of MSC related to downregulation of bcl-2 has also been mentioned [161], as well as high levels of intracellular reactive oxygen species (ROS). On the whole, MSC impairment in SLE results in reduced ability to generate regulatory $T$ cells. These defects of endogenous MSC in SLE prompted to allogeneic approaches, as confirmed by preclinical data obtained in two different strains of genetic murine models for SLE (Fas mutated MRL/Ipr and (NZB/NZW)F1) [162]. In 
this study, the authors demonstrated that adult MSC from lupus-prone mice failed to alleviate disease features compared with MSC from healthy mice. However, MSC from young mice displayed the same therapeutic effect, independently of the disease. Altogether, these results suggested an impact of the pathological environment on MSC rather than an intrinsic alteration of MSC preceding the disease onset. Nevertheless, in another study, the same group showed that SLE patients' MSC lacked therapeutic effects in MRL/lpr mice, compared with healthy donors' MSC [163]. All these data prompted to design studies using allogeneic healthy MSC rather than autologous cells.

Doing so, a therapeutic benefit has been observed using hBM-MSC from healthy donors as compared with conventional cyclophosphamide administration in two genetically-prone mouse models for SLE: MRL/lpr mice [164] [165] and BXSB mice [156]. Of note, conflicting results have been obtained in another major mouse model (NZB/NZW)F1: one study reported a complete failure of MSC-treatment [166], while another one showed protective effects only on glomerular involvement [167]. In studies with positive results, MSC-related benefits were associated with reduced levels of anti-ds-DNA Ab, less glomerular immune (IgG/C3) depositions, improved renal function and proteinuria, as well as bone formation. Interestingly, the successful use of human ASC in murine lupus has been reported [168-171], as well as human UC-MSC [172,173], with improved overall survival in both cases.

In human disease, a report of 2 patients by Carrion et al. in 2010 confirmed the lack of efficacy when using autologous SLE BM-MSC in this disease: no benefits observed, despite increased regulatory $T$ cell population [174]. In parallel, the first Chinese pilot clinical studies from Sun et al. shed light on the safety and potential benefits, using allogeneic BM-MSC (1 to $10 \times 10 \mathrm{e} 6$ cells per $\mathrm{kg}$ ) in 4 patients in 2009 
[156], and with 15 additional patients in 2010 [175], then using UC-MSC in 16 patients in 2010 [176]. In 2013, promising results were reported in 35 SLE patients with refractory cytopenia, who experienced good outcome on haematological manifestations following BM- or UC-MSC infusion. Patients exhibited decreased Th17 response and induced regulatory T cells [177]. UC-MSC transplantation was also reported in lupus alveolar haemorrhage, a very rare feature of the disease $[178,179]$. Of note, the same research group recently reported sustained results after a 4-year follow-up in these refractory cases where UC-MSC had been used. The good results were considered independent of cyclophosphamide administration, with about $50 \%$ remission, and $23 \%$ relapse [180]. Later on, Sun et al. described the benefits of allogeneic intra-familial BM-MSC administration (10e6/kg IV) in refractory lupus nephritis through an open label single centre study involving 81 patients [181]. After a 12-month follow-up, they noted $60,5 \%$ complete remission, associated with significant decrease in BILAG and SLEDAI scores, increased glomerular filtration rate, allowing tapering mean doses of prednisone, cyclophosphamide and mycophenolate mofetil. Of note, 2 patients died from heart failure (one severe pulmonary arterial hypertension) and 2 succumbed to disseminated pulmonary infections, which were considered as MSC-independent events.

Recently, the same group conducted a multicentre study on 40 patients with active refractory SLE (BILAG score A), who were treated by two consecutive infusions of $10 \mathrm{e} 6$ UC-MSC per $\mathrm{kg}$ at day 0 and day 7 [182]. They obtained $32.5 \%$ major clinical response (BILAG C or better), $27.5 \%$ partial response and $17.5 \%$ relapse, responding to another infusion at 6 months in most cases. Immunosuppressants were tapered significantly in most patients. Adverse events, not considered to be linked to MSC treatment included HSV infections in 3 cases, 
and tuberculosis in one case and three patients died. The causes of death were also considered as independent from MSC treatment and were acute heart failure 7 days after MSC infusion, severe pulmonary arterial hypertension at 8 months, and pulmonary infection during follow-up.

On the whole, the extensive work by L. Sun et al. is promising, but some limitations have to be noted. First, no randomized controlled trial has been published so far; second, all the studies concerned SLE patients from Asian ethnicity, and thus can hardly be extrapolated to other ethnic groups considering the variability in clinical features and prognosis according to ethnic origin in SLE. Hence, there is an urgent need for multicentre randomized controlled trials evaluating MSC-based treatment in SLE [7].

\subsection{Rheumatoid arthritis (RA)}

RA is one of the most frequent rheumatologic AID affecting about $1 \%$ of the population and associated with severe disability, altered quality of life but also systemic complications and a shortened life-span. Biotherapies targeting cytokines, B-lymphocytes or T/B cooperation, combined with methotrexate today allow optimal control of patients [183-186]. Nevertheless, biotherapies fail in $30 \%$ of patients and the potential of MSC-treatment has been evaluated early in RA. The first preclinical assays were in murine models such as collagen induced arthritis (CIA), a model based on specific antigen immunization using bovine collagen II. In this model, conflicting results have been reported, according to administration route, number and time of injections [187-189,36,85,129]. Notably, our team showed that beneficial effects required two IV injections in a narrow therapeutic window, around collagen boost [36]. On the whole, when positive, these studies reported a reduction in the 
incidence and the severity of arthritis (clinical scores based on the number of swollen joints and the measurement of paw swelling), a restoration of the balance between pro- and anti-inflammatory cytokines in lymph nodes and joints (down-regulation of Th1 and Th17 cells, up-regulation of IL10 producing regulatory T-cells), and less joint damage (histological scores). Neither MHC compatibility nor tissue origin of MSC did affect the results in CIA, with good outcome using ASC [190]. Of note, the articular benefits were due to systemic immunosuppressive effects, since MSC did not migrate to joints, and intra-articular injection of cells was less effective than intraperioneal or intravenous routes [68].

In human disease, a phase $\mathrm{I} / \mathrm{Il}$ uncontrolled study enrolling 136 patients recently reported the benefits of UC-MSC (4x10e7 cells IV) with an 8-month follow-up [191]. The authors described an improvement in all activity scores (DAS28, HAQ, ACR responses), in C-reactive protein and rheumatoid factor levels, together with an enhanced regulatory T-cell response. In case of relapse, a second dose at three months (M3) allowed 58\% patients to achieve ACR20 response, and no serious adverse effects were noted (notably, biological parameters were systematically screened). The same group conducted a similar study in juvenile idiopathic arthritis (JIA) where 10 patients received 2 doses of $4 \times 10$ e 7 UC-MSC IV at M0 and M3, and observed an improvement from M3 to M6, with reduced pro-inflammatory cytokines and enhanced regulatory T-cells population [192]. This study brought safety data using UC-MSC in children. However, results from this study have to be examined cautiously, since all patients received glucocorticoids concomitantly to MSC infusion.

\subsection{Sjögren syndrome (SgS)}


SgS associates glandular inflammatory infiltration responsible for sicca syndrome and various systemic manifestations, with a risk of B-cell lymphoma transformation. BM-MSC have been recently evaluated favourably in an animal model of SgS (NOD mice) [193]. The Chinese group of L. Sun also published a very elegant study in 2012, reporting impaired immunomodulatory properties of murine (NOD/Ltj) and human SgS MSC, as well as therapeutic effects of healthy MSC, both in SgS mice (10e5 BM-MSC) and in $24 \mathrm{SgS}$ patients (10e6 UC-MSC per kg) [194]. Of note, these patients presented various involvements ranging from mere sicca syndrome to systemic threatening events like nephropathy or neurological involvements. Good outcomes concerned SSDAI score, saliva flow rate and anti-SSA antibodies levels, after a 12-month follow-up. In mice, BM-MSC treatment was also associated with suppressed Th17 and Th1 responses, a switch towards regulatory and Th2 responses and a migration of cells to inflammatory salivary glands via SDF-1.

\subsection{Inflammatory Bowel Diseases (IBD): Crohn's Disease (CD) and Ulcerative Recto-Colitis (URC)}

MSC have been thoroughly evaluated in preclinical models of experimental colitis in various species, such as mice, guinea pigs, dogs, where they exerted antiinflammatory, anti-fibrotic and healing properties [195]. Clinical phase I studies were in favour of a healing potential of autologous MSC in case of fistulising complications during CD [195] [196]. Autologous BM-MSC were also beneficial in luminal CD [197] and a recent phase $1 / I I$ study gave promising results using allogeneic ASC [198]. A dozen of clinical studies using BM-MSC, ASC or UC-MSC in IBD are on going today (see clinicaltrials.gov). 


\subsection{Systemic vasculitides}

Systemic vasculitides are a heterogeneous group of systemic AID characterized by vascular inflammation sometimes in association with autoantibodies directed against neutrophils (anti-neutrophil cytoplasm antibodies, ANCA). Only two publications have reported so far the effects of MSC in vasculitides. First, a patient with ANCA-associated vasculitis and threatening renal involvement (rapidly progressive glomerulonephritis), refractory to rituximab was successfully treated with autologous BM-MSC $(1,5 \times 10 \mathrm{e} 6 / \mathrm{kg}$ IV) [199]. Within 7 days, this patient achieved complete clinical and biological remission (urinary sediment and autoantibodies), but required subsequent re-infusion for relapsing disease after 8 months. After a 20month follow-up, sustained remission persisted together with a reduction of auto $A b$, pro-inflammatory cytokines and induction of regulatory T-cell population. Second, Iranian authors recently reported a negative study, where they failed to treat 3

patients with intra-vitreous injection of autologous BM-MSC in severe retinal involvements during Behcet's disease [200]. However, these patients presented refractory vasculitis and were already blind when MSC were injected. The eventuality that earlier treatment could have improved these cases might be discussed, but was not investigated.

\subsection{Type 1 diabetes}

Cell therapy using allogeneic islet transplantation is used in the clinic in case of instable diabetes [201]. However, this procedure is limited by the necessity of a large amount of cells (namely, several donors for one recipient), and poor engraftment of these cells. Interestingly, combined transplantation using MSC was shown to prevent immune rejection of allogeneic islets and avoid immunosuppression [27]. hBM-MSC 
have also been evaluated in murine streptozotocin-induced diabetes and reported to improve glycemia [202] [133]. Current research focuses on in vitro differentiation of MSC into Langerhans islet beta cells for regenerative purposes [203].

\subsection{Multiple sclerosis (MS)}

Benefits have been reported using MSC in EAE, a murine model for multiple sclerosis (MS) based on myelin protein immunization (MOG for myelin oligodendrocyte glycoprotein or PLP for proteolipid proteins). In this model, MSC systemic administration proved to alleviate disease severity on the basis of clinical scores, biological and histological parameters (less demyelination and immune cells infiltration in both spinal cord and CNS parenchyma), whatever the time of injection, the tissue origin or MHC compatibility of cells [204] [205] [2]. Interestingly, preexposition of MSC to an anti-oxidant (resveratrol) augmented the neuroprotective potential of MSC in this model [206]. Promising results have been reported in human MS through phase $1 / /$ studies using various sources of MSC [207-210], and six studies are currently recruiting (see htpp://www.clinicaltrials.gov).

\subsection{Graft versus Host Disease (GvHD)}

Benefits from MSC-based therapy have been described in severe corticoresistant acute Graft versus Host Disease (GvHD), a complication of allogeneic hematopoietic stem cell transplantation (HSCT). In particular, phase II studies using BM-MSC demonstrated an improved survival in MSC-treated patients [132] [211]. Interestingly, ASC have been successfully used in murine and human disease [212] [213]. Clinical trials are also on going in this disease.

\subsection{Myasthenia gravis}


In experimental autoimmune myasthenia gravis (in mice or rats), MSC infusion reduced clinical symptoms, anti-Ach-receptor Ab levels, specific auto-reactive lymphocytes, and led to an increase in animal weight [214-216]. These results are promising for the treatment of myasthenia gravis in Humans.

To conclude, an important amount of data documented MSC immunomodulatory potential in AID, and helped decipher for each disease the best conditions of use as well as the mechanisms involved, mainly in preclinical models. However, since most clinical trials were phase I/II studies, they principally demonstrated the feasibility and safety of MSC-treatment in AID, and there still is an unmet need for randomized controlled trials to ascertain MSC efficacy in refractory AID.

\section{MSC IN SYSTEMIC SCLEROSIS: FIRST RESULTS AND PERSPECTIVES}

\subsection{General comments on systemic sclerosis}

SSc (or scleroderma) is a rare AID mainly affecting middle-aged women and characterized by multi-organ fibrosis, primarily concerning skin tissue but also lungs, heart, or digestive tract $[5,6,217]$. Beside excessive accumulation of collagen in tissues promoted by abnormal fibroblast activation [218], vascular abnormalities in SSc cause peripheral vascular disease such as Raynaud's phenomenon, telangiectasia, digital ulcers, but also pulmonary arterial hypertension and vascular renal crisis [219-224]. Auto-immunity in SSc is mediated by immune cell activation $[225,226]$, and production of autoantibodies directed against several autoantigens such as topoisomerase 1 (anti-topo1 or anti-scl70), centromere or RNA-polymerase III [227-230]. Clinical manifestations in SSc are highly variable upon disease classification (limited or diffuse forms) and are constantly responsible for substantial 
morbidity impacting quality of life [231-233]. On the whole, SSc has a severe prognosis associated with premature mortality, in particular in case of life-threatening complications such as pulmonary fibrosis, PAH and specific heart involvement or renal crisis [234-237]. SSc pathogenesis is a complex interplay of genetic and environmental factors [238-241], leading to fibroblast activation and endothelial impairment [242-244]. The role of endogenous and/or exogenous oxidative stress in SSc is crucial, as shown by the link between environmental exposure to oxidants and professional disease [240]. More specifically, we reported higher levels of Advanced Oxidation Protein Products (AOPP) in SSc patients' sera compared with healthy controls, responsible for fibroblast proliferation and endothelial cell apoptosis [245]. To date, treatment of SSc patients is mostly palliative, based on symptomatic drugs alleviating Raynaud's phenomenon, gastro-oesophageal reflux, pain, and immunosuppressants (methotrexate, mycophenolate mofetil, and cyclophosphamide), or organ transplantation in case of severe cardio-pulmonary involvement [246]. Although new drugs have been developed for the treatment of PAH [247], SSc general prognosis and mortality have not changed in the last 40 years [248], outlining the unmet medical need in this multifaceted intractable AID where immunosuppressive drugs have poor efficacy. The major breakthrough in the last decade came from the development of autologous haematopoietic stem cell transplantation (HSCT) to treat refractory SSc. Based on retrospective observations [249], phase $1 / I I$ pilot studies [250] and more recently through a randomized controlled trial [251], about 500 SSc patients, who underwent HSCT procedures, experienced clinical benefits that no other treatment had ever offered in SSc [252255,7]. Indeed, in ASTIS phase III trial comparing HSCT with 12-month IV pulses of cyclophosphamide, a dramatic improvement in clinical parameters (mean Rodnan 
Skin Score, mRSS) was observed, together with sustained clinical and immunological remission, leading to significant improvement in event-free and overall survival [251]. However, significant procedure-related mortality (about 1-2\% of patients, during the first year) prompts to accurately and carefully select patients with the most severe progressive disease who could benefit from this exceptional approach. This selection is particularly difficult considering the heterogeneity of the disease, where we still lack reliable prognostic markers. Anyhow, the development of this cell therapy in SSc brought new rationale and hopes for MSC-based therapy, especially as MSC could counteract the three main pathogenic axes of the disease: fibrosis, angiogenic defect, and autoimmunity (see figure, and [256,195,3,4,7]).

\subsection{MSC from SSc patients:}

A growing body of data concerning MSC from SSc patients (SSc-MSC) have been published in the last few years. First, in a French work comparing BM-MSC from 12 SSc patients with 13 healthy controls, it appeared that SSc-MSC displayed normal phenotype as defined by number and aspect of isolated CFU-F, with similar differentiation potential, immunosuppressive and haematopoietic support functions [257]. Similar results have been reported by another group in a study comparing BMMSC from AID patients with healthy controls, and including one SSc patient [258]. The generation of CFU-F, the differentiation potential and the capacity of this patient's BM-MSC to suppress lymphocyte proliferation in vitro was similar to MSC from healthy controls.

However, other studies demonstrated an alteration in differentiation potential into osteoblasts and adipocytes [259], and a loss in angiogenic potential characterized by impaired ability to generate endothelial progenitors, whose capacity 
to migrate and generate vessels was decreased $[259,260]$. Besides, SSc-MSC exhibited early senescence with higher telomerase activity [125,259], but maintained immunosuppressive functions and the capacity to generate regulatory $\mathrm{T}$-cells through adaptive mechanisms [261]. Similarly, Orciani et al. showed that SSc-MSC, although affected by SSc oxidative environment, could still counteract oxidative stress by improving anti-oxidant defences [126]. Guiducci et al. confirmed the alteration in angiogenic potential of SSc-MSC that constitutively overexpressed pro-angiogenic factors (i.e. VEGF-A) and over-stimulated angiogenesis in vitro [262,243]. This raised the issue of MSC intrinsic alteration leading to vasculopathy in SSc, although these alterations could result from adaptive mechanisms in the context of this disease.

Even more disturbingly, the aforementioned French study revealed an increase in TGF $\beta$-R2 at the surface of SSc-MSC compared with healthy MSC, and a higher sensibility to TGF $\beta$, leading to up-regulation of this pathway and excessive production of collagen 1 [263]. Lately, Cipriani et al. further investigated the possible link between angiopathy and fibrosis and highlighted the pivotal deleterious role played by SSc endothelial cells (EC) in this process, through a crosstalk with resident MSC [124]. In contact with SSc-EC, MSC phenotype was altered and contributed to tissue fibrosis (i.e. expression of $\alpha$-SMA and collagen 1). Thus, it has been hypothesized that resident MSC could contribute to SSc pathogenesis. To date, even if this question is not elucidated yet and merits further investigation, these observations could suggest that autologous MSC approaches could be more questionable than the allogeneic approaches for the treatment of SSc. Interestingly, Scuderi et al. reported no alterations in phenotype, differentiation potential or population doubling in ASC from 6 SSc patients compared with healthy ASC [264]. Although these results have to be reproduced with a higher number of patients, they 
might indicate that ASC do not display the alterations observed in BM-MSC from SSC patients. If confirmed, this could allow the use of autologous adipose tissue as a source of MSC in SSc.

\subsection{MSC in bleomycin murine model}

Several genetic pre-clinical models have been used to study SSc in the last 20 years, such as tight-skin mice (TSK1, TSK2), Fra-2 mice, TGF $\beta-R 2 \Delta \mathrm{k}$ mice and UCD200 chicken [265]. These models display variable features of the human disease, but rarely encompass the systemic nature of SSc, with simultaneous skin and lung fibrosis, together with vasculopathy and autoimmunity. Among chemically induced murine models, the bleomycin model is widely used to study fibrosis [265]. In this model, local injection of bleomycin, either in skin or lung (intra-tracheal, IT), triggers tissue inflammation and remodelling. Hence, this model allows studying acute lung injury, but does not induce chronic multi-visceral fibrosis, although this could be obtained with repeated intra-dermal injections of bleomycin [265].

So far, whereas no publication has reported the effect of MSC in SSc-genetic models or in bleomycin chronic systemic fibrosis, many studies have used MSC in bleomycin acute lung injury [266]. In 2003, Ortiz et al. first reported the short-term effects using a preventive IV infusion of $5 \times 10$ e5 allogenic BM-MSC at the time of bleomycin IT injection [51]. In this study, a reduction of fibrosis and inflammation was observed; MSC selectively migrated to injured parts of the lung, and were shown to differentiate into epithelial cells. Of note, when injected seven days after bleomycin challenge, MSC did not ameliorate tissue fibrosis. These observations were confirmed by Rojas et al. in 2005 [267], and in 2008 in bleomycin-challenged rats with the use of early (H12) infusion of syngeneic BM-MSC, associated with down- 
regulation of TGF $\beta$ pathway and collagen production at day 15 [52]. Kumamoto et al. reported similar anti-fibrotic effects using minimally vs conventionally cultured syngeneic BM-MSC (5x10e5 at day 3) [268]. Similarly, Moodley et al also reported successful use of UC-MSC (10e6 MSC at H24) into SCID mice [74]. No epithelial differentiation could be shown, but tissue remodelling was affected after MSC infusion with enhanced MMP1/TIMP1 ratio. Anti-inflammatory and anti-fibrotic effects were also observed using allogeneic BM-MSC or xenogeneic placenta-derived human MSC, whatever the route used (IT, IP or IV) [269]. Beside MSC homing to injured tissue (via CXCR4) and putative differentiation into epithelial cells, MSC were shown to reduce inflammation through IL1-RA [270] and TSG-6 secretion [271], to restore cytokine and NO balance (tissue down-regulation of TNF, IL1b, IL6, and iNOS) [272], and to modify tissue remodelling [266]. MSC antioxidant properties also contributed to anti-fibrotic effects and could be augmented by pre-exposition of cells to N-AcetylCysteine $[273,266]$. Altogether, these studies confirmed that early systemic or local administration of MSC, whatever the tissue origin and MHC matching, could improve the lung fibrotic manifestations consecutive to acute lung injury, mostly by resolving inflammation and avoiding pathological fibrotic healing. However, they did not offer a proof for chronic pauci-inflammatory fibrotic processes, nor for systemic disease, that characterize SSc.

\subsection{MSC in HOCl-SSc}

The demonstration that oxidative stress and AOPP were prominent in the physiopathology of SSc led to the development of a novel chemically induced model of SSc based on repeated exposure of mice to oxidants [274,70]. Among various oxidants evaluated (superoxide anions $\mathrm{O}^{-}$, hydroxyl radicals $\mathrm{OH}^{-}$, peroxynitrites $\left.\mathrm{ONOO}^{-}\right)$, hypochlorite $(\mathrm{HOCl})$ was shown to trigger skin and lung fibrosis, together 
with the production of anti-topo1 $\mathrm{Ab}$ and some vascular features, encompassing most features of SSc. The originality of this model lies in the possibility to investigate the systemic effects of a treatment in diffuse SSc where lung and skin fibrosis coexist. Hence, this relevant model, reproduced by other groups since the first publication in 2009 [274], allowed studying various pharmacological approaches to treat SSc [275284,70].

Recently, we demonstrated the therapeutic effects of BM-MSC in HOCl-SSc [70]. First, in a preventive approach, we compared three doses of syngeneic BMMSC, infused the day before HOCl-SSc induction, and showed inverse dose-effects on skin fibrosis, with the best reduction using the lowest dose of 2,5×10e5 BM-MSC. Reduction of skin and lung fibrosis was characterized by tissue down-regulation of collagen 1/3, $\alpha$-SMA and TGF $\beta 1$ expression at the mRNA level, total collagen deposition in tissue, inhibition of SMAD2/3 pathway and histological evidence. A decrease of anti-scl70 Ab and AOPP in sera was also noted. Similar benefits were observed in a curative approach infusing BM-MSC at mid-experiment. BM-MSC effects were mediated through the reduction of tissue inflammation with less macrophage and T-cell infiltrates and lower levels of pro-inflammatory cytokines (TNF, IL1, IL6). Improved tissue remodelling (MMP1/TIMP1 ratio) and oxidative status were also associated with BM-MSC infusion. Of note, BM-MSC did not migrate to skin, and were cleared from lungs within a couple of days. MHC compatibility of BM-MSC did not appear to influence beneficial outcomes in this model or biodistribution, with similar results using xenogeneic, allogeneic and syngeneic MSC while hASC seemed to be more potent than hBM-MSC, in particular in terms of immunomodulation and tissue remodelling (Maria et al., under revision). On the whole, the preclinical studies conducted in $\mathrm{HOCl}-\mathrm{SSc}$ murine model allowed to obtain 
original data regarding BM-MSC and ASC therapeutic effects in diffuse SSc. The potent and pleiotropic effects of ASC are therefore very promising in sight of clinical perspectives.

\subsection{Preliminary data in human SSc}

In the clinic, the specific application of MSC to SSc remains to be investigated. However, MSC-based applications in other fibrotic conditions can bring a lot about the feasibility and potentialities of MSC [285,195,286-290]. In SSc, Christopeit et al. reported the first compassionate use of allogeneic BM-MSC in one patient with severe refractory SSc, in 2008 [291]. MSC infusion was associated with a healing of digital ulcers within 3 months, improved blood flow and transcutaneous oxygen pressure at M6, an improvement of modified Rodnan skin score (mRSS, 11 vs 25), but no change in immunological parameters. In 2011, the same German team published four more cases of refractory SSc treated with allogeneic BM-MSC [292]. At 18-month follow-up, no major adverse event was reported, and four over five patients had an improvement in mRSS, digital ulcers or distal limb necrosis. Guiducci et al. also reported a case of SSc acute gangrene of upper and lower limbs treated with autologous BM-MSC [293]. Complete healing was obtained and angiography showed limb revascularization after MSC infusion.

Recently, the benefits from SVF, obtained from adipose tissue, were reported in SSc. Indeed, Granel et al. evaluated the feasibility and safety of local injections of autologous SVF in of 12 SSc patients' fingers, with promising results after six month of follow-up, in terms of doppler evaluation, skin score $(-2,4$ points in mRSS), Cochin's Hand Functional Score, Raynaud's condition score, and quality of life [294]. However, the proportion of ASC and other cells contained in SVF is variable from 
one sample to another, leading expectedly to poor reproducibility and unpredictable effects. Thus, the use of SVF for broader applications is likely limited, considering that the heterogeneity of preparations and the difficulty of standardization are major obstacles to GMP applications.

On the contrary, ASC are a rather homogeneous population of cells in terms of phenotype and function and the isolation and expansion procedures comply with GMP standards. In SSc, only one study by Scuderi et al. reported the use of ASC in affected skin areas (face or limbs) from six SSc patients together with the injection of acid hyaluronic, with a good reduction of skin thickness and no local complication of the injections [264]. The promising results from this study together with our findings in murine $\mathrm{HOCl}-\mathrm{SSc}$ argue for the interest of evaluating the therapeutic effect of ASC in human SSc.

\subsection{Perspectives}

A French clinical multicentre phase I/II study, evaluating BM-MSC from intrafamilial donor in severe refractory SSc is currently on going (NCT02213705, clinicaltrials.gov). If promising results are expected, randomized controlled trials are still needed to assert MSC benefits in SSc. Considering the accessibility of adipose tissue, the high yield at isolation and the therapeutic potential of these cells, ASC offer a very attractive perspective in further clinical trials.

\section{CONCLUSION AND PERSPECTIVES}

Taken together, the work carried out in the last decade demonstrated that MSC might represent an innovative strategy to cure AID. In particular, MSC displaying immunosuppressive, anti-fibrotic, pro-angiogenic and anti-oxidative responses, 
harbor new hope for the treatment of SSc, a multifaceted intractable AID with unmet medical need. While a first clinical trial using MSC in SSc has been launched in France, results obtained in preclinical models, as well as the few case reports in the human disease are very promising. Considering that MSC mainly act through a "hit and run" mechanism, involving paracrine, endocrine and extracellular vesicles secretion, the use of allogeneic MSC seems a reasonable setting to treat AID, where resident MSC might be impaired and even contribute to disease progression. Regarding the source for MSC, the current knowledge prompts to investigate diverse sources of MSC, among which adipose tissue is highly promising. In that context, the convincing effects obtained with ASC in the $\mathrm{HOCl}$ preclinical model, and in other AID, are particularly appealing for the treatment of SSc. However, further studies will have to focus on better characterization of MSC/ASC functionality and the development of potency assays, in order to individualize cell-therapy according to patient's needs, and develop relevant randomized controlled trials in SSc. 


\section{Legend to figure:}

Systemic sclerosis (SSc) is a rare connective tissue disorder characterized by multiorgan fibrosis, vascular dysfunction and autoreactivity against self-antigens. Oxidative stress and reactive oxygen species (ROS) have been shown to amplify the pathological process. Displaying immunosuppressive, trophic and antioxidant capacities, mesenchymal stem cells (MSCs) could counteract the three main pathological axes of the disease and restore antioxidant balance.

\section{References}

1. Zhao Y, Mazzone T (2010) Human cord blood stem cells and the journey to a cure for type 1 diabetes. Autoimmun Rev 10 (2):103-107. doi:10.1016/j.autrev.2010.08.011

2. Ben-Ami E, Berrih-Aknin S, Miller A (2011) Mesenchymal stem cells as an immunomodulatory therapeutic strategy for autoimmune diseases. Autoimmun Rev 10 (7):410-415. doi:10.1016/j.autrev.2011.01.005

3. Cipriani P, Carubbi F, Liakouli V, Marrelli A, Perricone C, Perricone R, Alesse E, Giacomelli R (2013) Stem cells in autoimmune diseases: Implications for pathogenesis and future trends in therapy. Autoimmunity reviews 12 (7):709-716. doi:10.1016/j.autrev.2012.10.004

4. Cipriani P, Ruscitti P, Di Benedetto P, Carubbi F, Liakouli V, Berardicurti O, Ciccia F, Triolo G, Giacomelli R (2015) Mesenchymal stromal cells and rheumatic diseases: new tools from pathogenesis to regenerative therapies. Cytotherapy 17 (7):832-849. doi:10.1016/j.jcyt.2014.12.006

5. Chighizola C, Shoenfeld Y, Meroni PL (2011) Systemic sclerosis. Introduction. Autoimmun Rev 10 (5):239-240. doi:10.1016/j.autrev.2011.02.005

6. Desbois AC, Cacoub P (2016) Systemic sclerosis: An update in 2016. Autoimmun Rev. doi:10.1016/j.autrev.2016.01.007

7. Cras A, Farge D, Carmoi T, Lataillade JJ, Wang DD, Sun L (2015) Update on mesenchymal stem cell-based therapy in lupus and scleroderma. Arthritis Res Ther 17:301. doi:10.1186/s13075-015-0819-7

8. Friedenstein AJ, Gorskaja JF, Kulagina NN (1976) Fibroblast precursors in normal and irradiated mouse hematopoietic organs. Exp Hematol 4 (5):267-274

9. Lv FJ, Tuan RS, Cheung KM, Leung VY (2014) Concise review: the surface markers and identity of human mesenchymal stem cells. Stem Cells 32 (6):14081419. doi:10.1002/stem. 1681

10. Lazarus HM, Haynesworth SE, Gerson SL, Rosenthal NS, Caplan AI (1995) Ex vivo expansion and subsequent infusion of human bone marrow-derived stromal progenitor cells (mesenchymal progenitor cells): implications for therapeutic use. Bone Marrow Transplant 16 (4):557-564 
11. Horwitz EM, Le Blanc K, Dominici M, Mueller I, Slaper-Cortenbach I, Marini FC, Deans RJ, Krause DS, Keating A, International Society for Cellular T (2005) Clarification of the nomenclature for MSC: The International Society for Cellular $\begin{array}{lllll}\text { Therapy position statement. } & \text { Cytotherapy } & 7 & \text { (5):393-395. }\end{array}$ doi:10.1080/14653240500319234

12. Dominici M, Le Blanc K, Mueller I, Slaper-Cortenbach I, Marini F, Krause D, Deans R, Keating A, Prockop D, Horwitz E (2006) Minimal criteria for defining multipotent mesenchymal stromal cells. The International Society for Cellular $\begin{array}{lllll}\text { Therapy position statement. Cytotherapy } 8 & (4): 315-317 .\end{array}$ doi:10.1080/14653240600855905

13. Nauta AJ, Fibbe WE (2007) Immunomodulatory properties of mesenchymal stromal cells. Blood 110 (10):3499-3506. doi:10.1182/blood-2007-02-069716

14. Maumus M, Peyrafitte JA, D'Angelo R, Fournier-Wirth C, Bouloumie A, Casteilla L, Sengenes C, Bourin P (2011) Native human adipose stromal cells: localization, morphology and phenotype. Int $J$ Obes (Lond) 35 (9):1141-1153. doi:10.1038/ijo.2010.269

15. Tropel $P$, Noel D, Platet N, Legrand P, Benabid AL, Berger F (2004) Isolation and characterisation of mesenchymal stem cells from adult mouse bone marrow. Exp Cell Res 295 (2):395-406. doi:10.1016/j.yexcr.2003.12.030

16. Samsonraj RM, Rai B, Sathiyanathan P, Puan KJ, Rotzschke O, Hui JH, Raghunath M, Stanton LW, Nurcombe V, Cool SM (2015) Establishing criteria for human mesenchymal stem cell potency. Stem Cells 33 (6):1878-1891. doi:10.1002/stem.1982

17. Galipeau J, Krampera M, Barrett J, Dazzi F, Deans RJ, DeBruijn J, Dominici M, Fibbe WE, Gee AP, Gimble JM, Hematti P, Koh MB, LeBlanc K, Martin I, McNiece IK, Mendicino M, Oh S, Ortiz L, Phinney DG, Planat V, Shi Y, Stroncek DF, Viswanathan S, Weiss DJ, Sensebe L (2016) International Society for Cellular Therapy perspective on immune functional assays for mesenchymal stromal cells as potency release criterion for advanced phase clinical trials. Cytotherapy 18 (2):151-159. doi:10.1016/j.jcyt.2015.11.008

18. Bravery CA, Carmen J, Fong T, Oprea W, Hoogendoorn KH, Woda J, Burger SR, Rowley JA, Bonyhadi ML, Van't Hof W (2013) Potency assay development for cellular therapy products: an ISCT review of the requirements and experiences in the industry. Cytotherapy 15 (1):9-19. doi:10.1016/j.jcyt.2012.10.008

19. Menard C, Pacelli L, Bassi G, Dulong J, Bifari F, Bezier I, Zanoncello J, Ricciardi M, Latour M, Bourin P, Schrezenmeier H, Sensebe L, Tarte K, Krampera M (2013) Clinical-grade mesenchymal stromal cells produced under various good manufacturing practice processes differ in their immunomodulatory properties: standardization of immune quality controls. Stem Cells Dev 22 (12):1789-1801. doi:10.1089/scd.2012.0594

20. Mendicino M, Bailey AM, Wonnacott K, Puri RK, Bauer SR (2014) MSC-based product characterization for clinical trials: an FDA perspective. Cell Stem Cell 14 (2):141-145. doi:10.1016/j.stem.2014.01.013

21. Sensebe L, Gadelorge M, Fleury-Cappellesso S (2013) Production of mesenchymal stromal/stem cells according to good manufacturing practices: a review. Stem Cell Res Ther 4 (3):66. doi:10.1186/scrt217

22. Bartholomew A, Sturgeon C, Siatskas M, Ferrer K, Mclntosh K, Patil S, Hardy W, Devine S, Ucker D, Deans R, Moseley A, Hoffman R (2002) Mesenchymal stem cells suppress lymphocyte proliferation in vitro and prolong skin graft survival in vivo. Exp Hematol 30 (1):42-48 
23. Deans RJ, Moseley AB (2000) Mesenchymal stem cells: biology and potential clinical uses. Exp Hematol 28 (8):875-884

24. Ghannam S, Bouffi C, Djouad F, Jorgensen C, Noel D (2010) Immunosuppression by mesenchymal stem cells: mechanisms and clinical applications. Stem Cell Res Ther 1 (1):2. doi:10.1186/scrt2

25. Krampera M, Galipeau J, Shi Y, Tarte K, Sensebe L, Therapy MSCCotISfC (2013) Immunological characterization of multipotent mesenchymal stromal cells-The International Society for Cellular Therapy (ISCT) working proposal. Cytotherapy 15 (9):1054-1061. doi:10.1016/j.jcyt.2013.02.010

26. Waterman RS, Tomchuck SL, Henkle SL, Betancourt AM (2010) A new mesenchymal stem cell (MSC) paradigm: polarization into a pro-inflammatory MSC1 or an Immunosuppressive MSC2 phenotype. PLoS One 5 (4):e10088. doi:10.1371/journal.pone.0010088

27. Solari MG, Srinivasan S, Boumaza I, Unadkat J, Harb G, Garcia-Ocana A, FeiliHariri M (2009) Marginal mass islet transplantation with autologous mesenchymal stem cells promotes long-term islet allograft survival and sustained normoglycemia. J Autoimmun 32 (2):116-124. doi:10.1016/j.jaut.2009.01.003

28. Ren G, Zhang L, Zhao X, Xu G, Zhang Y, Roberts Al, Zhao RC, Shi Y (2008) Mesenchymal stem cell-mediated immunosuppression occurs via concerted action of chemokines and nitric oxide. Cell Stem Cell 2 (2):141-150. doi:10.1016/j.stem.2007.11.014

29. Noel D, Djouad F, Bouffi C, Mrugala D, Jorgensen C (2007) Multipotent mesenchymal stromal cells and immune tolerance. Leuk Lymphoma 48 (7):12831289. doi:10.1080/10428190701361869

30. Jorgensen C, Djouad F, Apparailly F, Noel D (2003) Engineering mesenchymal stem cells for immunotherapy. Gene Ther 10 (10):928-931. doi:10.1038/sj.gt.3302019

31. Ankrum JA, Ong JF, Karp JM (2014) Mesenchymal stem cells: immune evasive, not immune privileged. Nature biotechnology 32 (3):252-260. doi:10.1038/nbt.2816

32. Meisel R, Brockers S, Heseler K, Degistirici O, Bulle H, Woite C, Stuhlsatz S, Schwippert W, Jager M, Sorg R, Henschler R, Seissler J, Dilloo D, Daubener W (2011) Human but not murine multipotent mesenchymal stromal cells exhibit broadspectrum antimicrobial effector function mediated by indoleamine 2,3-dioxygenase. Leukemia 25 (4):648-654. doi:10.1038/leu.2010.310

33. Meisel R, Zibert A, Laryea M, Gobel U, Daubener W, Dilloo D (2004) Human bone marrow stromal cells inhibit allogeneic T-cell responses by indoleamine 2,3dioxygenase-mediated tryptophan degradation. Blood 103 (12):4619-4621. doi:10.1182/blood-2003-11-3909

34. Djouad F, Bouffi C, Ghannam S, Noel D, Jorgensen C (2009) Mesenchymal stem cells: innovative therapeutic tools for rheumatic diseases. Nat Rev Rheumatol 5 (7):392-399. doi:10.1038/nrrheum.2009.104

35. Nemeth K, Leelahavanichkul A, Yuen PS, Mayer B, Parmelee A, Doi K, Robey PG, Leelahavanichkul K, Koller BH, Brown JM, Hu X, Jelinek I, Star RA, Mezey E (2009) Bone marrow stromal cells attenuate sepsis via prostaglandin $E(2)$-dependent reprogramming of host macrophages to increase their interleukin-10 production. Nat Med 15 (1):42-49. doi:10.1038/nm.1905

36. Bouffi C, Bony C, Courties G, Jorgensen C, Noel D (2010) IL-6-dependent PGE2 secretion by mesenchymal stem cells inhibits local inflammation in experimental arthritis. PloS one 5 (12):e14247. doi:10.1371/journal.pone.0014247 
37. Luz-Crawford P, Djouad F, Toupet K, Bony C, Franquesa M, Hoogduijn MJ, Jorgensen C, Noel D (2015) Mesenchymal stem cell-derived IL1RA promotes macrophage polarization and inhibits $B$ cell differentiation. Stem Cells. doi:10.1002/stem.2254

38. Ke F, Zhang L, Liu Z, Yan S, Xu Z, Bai J, Zhu H, Lou F, Cai W, Sun Y, Gao Y, Wang H, Wang H (2016) Soluble Tumor Necrosis Factor Receptor 1 Released by Skin-Derived Mesenchymal Stem Cells Is Critical for Inhibiting Th17 Cell Differentiation. Stem Cells Transl Med. doi:10.5966/sctm.2015-0179

39. Luz-Crawford P, Tejedor G, Mausset-Bonnefont AL, Beaulieu E, Morand EF, Jorgensen C, Noel D, Djouad F (2015) Glucocorticoid-induced leucine zipper governs the therapeutic potential of mesenchymal stem cells by inducing a switch from pathogenic to regulatory Th17 cells in a mouse model of collagen-induced arthritis. Arthritis Rheumatol 67 (6):1514-1524. doi:10.1002/art.39069

40. Luz-Crawford P, Noel D, Fernandez X, Khoury M, Figueroa F, Carrion F, Jorgensen C, Djouad F (2012) Mesenchymal stem cells repress Th17 molecular program through the PD-1 pathway. PLoS One 7 (9):e45272. doi:10.1371/journal.pone.0045272

41. Luz-Crawford P, Kurte M, Bravo-Alegria J, Contreras R, Nova-Lamperti E, Tejedor G, Noel D, Jorgensen C, Figueroa F, Djouad F, Carrion F (2013) Mesenchymal stem cells generate a CD4+CD25+Foxp3+ regulatory $T$ cell population during the differentiation process of Th1 and Th17 cells. Stem Cell Res Ther 4 (3):65. doi:10.1186/scrt216

42. Sotiropoulou PA, Perez SA, Gritzapis AD, Baxevanis CN, Papamichail M (2006) Interactions between human mesenchymal stem cells and natural killer cells. Stem Cells 24 (1):74-85. doi:10.1634/stemcells.2004-0359

43. Corcione A, Benvenuto F, Ferretti E, Giunti D, Cappiello V, Cazzanti F, Risso M, Gualandi F, Mancardi GL, Pistoia V, Uccelli A (2006) Human mesenchymal stem cells modulate B-cell functions. Blood 107 (1):367-372. doi:10.1182/blood-2005-072657

44. Rosado MM, Bernardo ME, Scarsella M, Conforti A, Giorda E, Biagini S, Cascioli S, Rossi F, Guzzo I, Vivarelli M, Dello Strologo L, Emma F, Locatelli F, Carsetti R (2015) Inhibition of B-cell proliferation and antibody production by mesenchymal stromal cells is mediated by $T$ cells. Stem Cells Dev 24 (1):93-103. doi:10.1089/scd.2014.0155

45. Djouad F, Charbonnier LM, Bouffi C, Louis-Plence P, Bony C, Apparailly F, Cantos C, Jorgensen C, Noel D (2007) Mesenchymal stem cells inhibit the differentiation of dendritic cells through an interleukin-6-dependent mechanism. Stem Cells 25 (8):2025-2032. doi:10.1634/stemcells.2006-0548

46. Jiang XX, Zhang Y, Liu B, Zhang SX, Wu Y, Yu XD, Mao N (2005) Human mesenchymal stem cells inhibit differentiation and function of monocyte-derived dendritic cells. Blood 105 (10):4120-4126. doi:10.1182/blood-2004-02-0586

47. Najar M, Raicevic G, Fayyad-Kazan H, Bron D, Toungouz M, Lagneaux L (2016) Mesenchymal stromal cells and immunomodulation: A gathering of regulatory immune cells. Cytotherapy 18 (2):160-171. doi:10.1016/j.jcyt.2015.10.011

48. Djouad F, Plence P, Bony C, Tropel P, Apparailly F, Sany J, Noel D, Jorgensen C (2003) Immunosuppressive effect of mesenchymal stem cells favors tumor growth in allogeneic animals. Blood 102 (10):3837-3844. doi:10.1182/blood-2003-04-1193

49. Patel DM, Shah J, Srivastava AS (2013) Therapeutic potential of mesenchymal stem cells in regenerative medicine. Stem Cells Int 2013:496218. doi:10.1155/2013/496218 
50. Hwang NS, Zhang C, Hwang YS, Varghese S (2009) Mesenchymal stem cell differentiation and roles in regenerative medicine. Wiley Interdiscip Rev Syst Biol Med 1 (1):97-106. doi:10.1002/wsbm.26

51. Ortiz LA, Gambelli F, McBride C, Gaupp D, Baddoo M, Kaminski N, Phinney DG (2003) Mesenchymal stem cell engraftment in lung is enhanced in response to bleomycin exposure and ameliorates its fibrotic effects. Proceedings of the National Academy of Sciences of the United States of America 100 (14):8407-8411. doi:10.1073/pnas.1432929100

52. Zhao F, Zhang YF, Liu YG, Zhou JJ, Li ZK, Wu CG, Qi HW (2008) Therapeutic effects of bone marrow-derived mesenchymal stem cells engraftment on bleomycininduced lung injury in rats. Transplant Proc 40 (5):1700-1705. doi:S00411345(08)00471-5 [pii]

10.1016/j.transproceed.2008.01.080

53. Croft AP, Przyborski SA (2006) Formation of neurons by non-neural adult stem cells: potential mechanism implicates an artifact of growth in culture. Stem Cells 24 (8):1841-1851. doi:10.1634/stemcells.2005-0609

54. von Bahr L, Batsis I, Moll G, Hagg M, Szakos A, Sundberg B, Uzunel M, Ringden $\mathrm{O}$, Le Blanc K (2012) Analysis of tissues following mesenchymal stromal cell therapy in humans indicates limited long-term engraftment and no ectopic tissue formation. Stem cells 30 (7):1575-1578. doi:10.1002/stem.1118

55. Huang K, Kang X, Wang X, Wu S, Xiao J, Li Z, Wu X, Zhang W (2015) Conversion of bone marrow mesenchymal stem cells into type II alveolar epithelial cells reduces pulmonary fibrosis by decreasing oxidative stress in rats. Mol Med Rep 11 (3):1685-1692. doi:10.3892/mmr.2014.2981

56. Hashemi SM, Ghods S, Kolodgie FD, Parcham-Azad K, Keane M, Hamamdzic D, Young R, Rippy MK, Virmani R, Litt H, Wilensky RL (2008) A placebo controlled, dose-ranging, safety study of allogenic mesenchymal stem cells injected by endomyocardial delivery after an acute myocardial infarction. European heart journal 29 (2):251-259. doi:10.1093/eurheartj/ehm559

57. Leroy A, Nottelet B, Bony C, Pinese C, Charlot B, Garric X, Noel D, Coudane J (2015) PLA-poloxamer/poloxamine copolymers for ligament tissue engineering: sound macromolecular design for degradable scaffolds and MSC differentiation. Biomater Sci 3 (4):617-626. doi:10.1039/c4bm00433g

58. Bouffi C, Thomas O, Bony C, Giteau A, Venier-Julienne MC, Jorgensen C, Montero-Menei C, Noel D (2010) The role of pharmacologically active microcarriers releasing TGF-beta3 in cartilage formation in vivo by mesenchymal stem cells. Biomaterials 31 (25):6485-6493. doi:10.1016/j.biomaterials.2010.05.013

59. Jorgensen C, Gordeladze J, Noel D (2004) Tissue engineering through autologous mesenchymal stem cells. Curr Opin Biotechnol 15 (5):406-410. doi:10.1016/j.copbio.2004.08.003

60. Vinatier C, Bouffi C, Merceron C, Gordeladze J, Brondello JM, Jorgensen C, Weiss P, Guicheux J, Noel D (2009) Cartilage tissue engineering: towards a biomaterial-assisted mesenchymal stem cell therapy. Curr Stem Cell Res Ther 4 (4):318-329

61. Mathieu M, Vigier S, Labour MN, Jorgensen C, Belamie E, Noel D (2014) Induction of mesenchymal stem cell differentiation and cartilage formation by crosslinker-free collagen microspheres. Eur Cell Mater 28:82-96; discussion 96-87

62. Morille M, Van-Thanh T, Garric X, Cayon J, Coudane J, Noel D, Venier-Julienne MC, Montero-Menei CN (2013) New PLGA-P188-PLGA matrix enhances TGF-beta3 release from pharmacologically active microcarriers and promotes chondrogenesis of 
mesenchymal stem cells. J Control Release 170 (1):99-110. doi:10.1016/j.jconrel.2013.04.017

63. Portron S, Hivernaud V, Merceron C, Lesoeur J, Masson M, Gauthier O, Vinatier C, Beck L, Guicheux J (2015) Inverse regulation of early and late chondrogenic differentiation by oxygen tension provides cues for stem cell-based cartilage tissue engineering. Cell Physiol Biochem 35 (3):841-857. doi:10.1159/000369742

64. Eap S, Keller L, Schiavi J, Huck O, Jacomine L, Fioretti F, Gauthier C, Sebastian V, Schwinte P, Benkirane-Jessel N (2015) A living thick nanofibrous implant bifunctionalized with active growth factor and stem cells for bone regeneration. Int $\mathrm{J}$ Nanomedicine 10:1061-1075. doi:10.2147/IJN.S72670

65. Kim IG, Ko J, Lee HR, Do SH, Park K (2016) Mesenchymal cells condensationinducible mesh scaffolds for cartilage tissue engineering. Biomaterials 85:18-29. doi:10.1016/j.biomaterials.2016.01.048

66. Pers YM, Ruiz M, Noel D, Jorgensen C (2015) Mesenchymal stem cells for the management of inflammation in osteoarthritis: state of the art and perspectives. Osteoarthritis Cartilage 23 (11):2027-2035. doi:10.1016/j.joca.2015.07.004

67. Maumus M, Jorgensen C, Noel D (2013) Mesenchymal stem cells in regenerative medicine applied to rheumatic diseases: role of secretome and exosomes. Biochimie 95 (12):2229-2234. doi:10.1016/j.biochi.2013.04.017

68. Toupet K, Maumus M, Luz-Crawford P, Lombardo E, Lopez-Belmonte J, van Lent P, Garin MI, van den Berg W, Dalemans W, Jorgensen C, Noel D (2015) Survival and biodistribution of xenogenic adipose mesenchymal stem cells is not affected by the degree of inflammation in arthritis. PLoS One 10 (1):e0114962. doi:10.1371/journal.pone.0114962

69. Toupet K, Maumus M, Peyrafitte JA, Bourin P, van Lent PL, Ferreira R, Orsetti B, Pirot N, Casteilla L, Jorgensen C, Noel D (2013) Long-term detection of human adipose-derived mesenchymal stem cells after intraarticular injection in SCID mice. Arthritis Rheum 65 (7):1786-1794. doi:10.1002/art.37960

70. Maria AT, Toupet K, Bony C, Pirot N, Vozenin MC, Petit B, Roger P, Batteux F, Le Quellec A, Jorgensen C, Noel D, Guilpain P (2015) Anti-fibrotic, anti-oxidant and immunomodulatory effects of mesenchymal stem cells in $\mathrm{HOCl}$-induced systemic sclerosis. Arthritis Rheumatol. doi:10.1002/art.39477

71. Meyerrose TE, De Ugarte DA, Hofling AA, Herrbrich PE, Cordonnier TD, Shultz LD, Eagon JC, Wirthlin L, Sands MS, Hedrick MA, Nolta JA (2007) In vivo distribution of human adipose-derived mesenchymal stem cells in novel xenotransplantation models. Stem Cells 25 (1):220-227. doi:10.1634/stemcells.2006-0243

72. Gao J, Dennis JE, Muzic RF, Lundberg M, Caplan Al (2001) The dynamic in vivo distribution of bone marrow-derived mesenchymal stem cells after infusion. Cells Tissues Organs 169 (1):12-20. doi:47856

73. Fischer UM, Harting MT, Jimenez F, Monzon-Posadas WO, Xue H, Savitz SI, Laine GA, Cox CS, Jr. (2009) Pulmonary passage is a major obstacle for intravenous stem cell delivery: the pulmonary first-pass effect. Stem Cells Dev 18 (5):683-692. doi:10.1089/scd.2008.0253

74. Moodley Y, Atienza D, Manuelpillai U, Samuel CS, Tchongue J, llancheran S, Boyd R, Trounson A (2009) Human umbilical cord mesenchymal stem cells reduce fibrosis of bleomycin-induced lung injury. The American journal of pathology 175 (1):303-313. doi:S0002-9440(10)60545-7 [pii]

\subsection{3/ajpath.2009.080629}

75. Wolf D, Reinhard A, Seckinger A, Katus HA, Kuecherer H, Hansen A (2009) Dose-dependent effects of intravenous allogeneic mesenchymal stem cells in the 
infarcted porcine heart. Stem cells and development 18 (2):321-329. doi:10.1089/scd.2008.0019

76. Joo SY, Cho KA, Jung YJ, Kim HS, Park SY, Choi YB, Hong KM, Woo SY, Seoh JY, Cho SJ, Ryu KH (2010) Mesenchymal stromal cells inhibit graft-versus-host disease of mice in a dose-dependent manner. Cytotherapy 12 (3):361-370. doi:10.3109/14653240903502712

77. Desando G, Cavallo C, Sartoni F, Martini L, Parrilli A, Veronesi F, Fini M, Giardino R, Facchini A, Grigolo B (2013) Intra-articular delivery of adipose derived stromal cells attenuates osteoarthritis progression in an experimental rabbit model. Arthritis research \& therapy 15 (1):R22. doi:10.1186/ar4156

78. Murphy MB, Moncivais K, Caplan Al (2013) Mesenchymal stem cells: environmentally responsive therapeutics for regenerative medicine. Experimental \& molecular medicine 45:e54. doi:10.1038/emm.2013.94

79. Le Blanc K, Mougiakakos D (2012) Multipotent mesenchymal stromal cells and the innate immune system. Nat Rev Immunol 12 (5):383-396. doi:10.1038/nri3209

80. Spaggiari GM, Capobianco A, Becchetti S, Mingari MC, Moretta L (2006) Mesenchymal stem cell-natural killer cell interactions: evidence that activated NK cells are capable of killing MSCs, whereas MSCs can inhibit IL-2-induced NK-cell proliferation. Blood 107 (4):1484-1490. doi:10.1182/blood-2005-07-2775

81. Nauta AJ, Westerhuis G, Kruisselbrink AB, Lurvink EG, Willemze R, Fibbe WE (2006) Donor-derived mesenchymal stem cells are immunogenic in an allogeneic host and stimulate donor graft rejection in a nonmyeloablative setting. Blood 108 (6):2114-2120. doi:10.1182/blood-2005-11-011650

82. Crop MJ, Korevaar SS, de Kuiper R, JN IJ, van Besouw NM, Baan CC, Weimar W, Hoogduijn MJ (2011) Human mesenchymal stem cells are susceptible to lysis by CD8(+) T cells and NK cells. Cell Transplant 20 (10):1547-1559. doi:10.3727/096368910X564076

83. Lim R, Milton P, Murphy SV, Dickinson H, Chan ST, Jenkin G (2013) Human mesenchymal stem cells reduce lung injury in immunocompromised mice but not in immunocompetent mice. Respiration 85 (4):332-341. doi:10.1159/000343078

84. Breitbach $M$, Bostani $T$, Roell W, Xia Y, Dewald O, Nygren JM, Fries JW, Tiemann K, Bohlen H, Hescheler J, Welz A, Bloch W, Jacobsen SE, Fleischmann BK (2007) Potential risks of bone marrow cell transplantation into infarcted hearts. Blood 110 (4):1362-1369. doi:10.1182/blood-2006-12-063412

85. Bouffi C, Djouad F, Mathieu M, Noel D, Jorgensen C (2009) Multipotent mesenchymal stromal cells and rheumatoid arthritis: risk or benefit? Rheumatology (Oxford) 48 (10):1185-1189. doi:10.1093/rheumatology/kep162

86. Mishra PJ, Mishra PJ, Glod JW, Banerjee D (2009) Mesenchymal stem cells: flip side of the coin. Cancer Res 69 (4):1255-1258. doi:10.1158/0008-5472.CAN-08-3562 87. Miura M, Miura Y, Padilla-Nash HM, Molinolo AA, Fu B, Patel V, Seo BM, Sonoyama W, Zheng JJ, Baker CC, Chen W, Ried T, Shi S (2006) Accumulated chromosomal instability in murine bone marrow mesenchymal stem cells leads to malignant transformation. Stem Cells 24 (4):1095-1103. doi:10.1634/stemcells.20050403

88. Tolar J, Nauta AJ, Osborn MJ, Panoskaltsis Mortari A, McElmurry RT, Bell S, Xia L, Zhou N, Riddle M, Schroeder TM, Westendorf JJ, Mclvor RS, Hogendoorn PC, Szuhai K, Oseth L, Hirsch B, Yant SR, Kay MA, Peister A, Prockop DJ, Fibbe WE, Blazar BR (2007) Sarcoma derived from cultured mesenchymal stem cells. Stem Cells 25 (2):371-379. doi:10.1634/stemcells.2005-0620 
89. Tarte K, Gaillard J, Lataillade JJ, Fouillard L, Becker M, Mossafa H, Tchirkov A, Rouard H, Henry C, Splingard M, Dulong J, Monnier D, Gourmelon P, Gorin NC, Sensebe L, Societe Francaise de Greffe de Moelle et Therapie C (2010) Clinicalgrade production of human mesenchymal stromal cells: occurrence of aneuploidy without transformation. Blood 115 (8):1549-1553. doi:10.1182/blood-2009-05-219907 90. Bernardo ME, Zaffaroni N, Novara F, Cometa AM, Avanzini MA, Moretta A, Montagna D, Maccario R, Villa R, Daidone MG, Zuffardi O, Locatelli F (2007) Human bone marrow derived mesenchymal stem cells do not undergo transformation after long-term in vitro culture and do not exhibit telomere maintenance mechanisms. Cancer Res 67 (19):9142-9149. doi:10.1158/0008-5472.CAN-06-4690

91. Djouad F, Bony C, Apparailly F, Louis-Plence P, Jorgensen C, Noel D (2006) Earlier onset of syngeneic tumors in the presence of mesenchymal stem cells. Transplantation 82 (8):1060-1066. doi:10.1097/01.tp.0000236098.13804.0b

92. Lalu MM, Mclntyre L, Pugliese C, Fergusson D, Winston BW, Marshall JC, Granton J, Stewart DJ, Canadian Critical Care Trials G (2012) Safety of cell therapy with mesenchymal stromal cells (SafeCell): a systematic review and meta-analysis of clinical trials. PLoS One 7 (10):e47559. doi:10.1371/journal.pone.0047559

93. da Silva Meirelles L, Chagastelles PC, Nardi NB (2006) Mesenchymal stem cells reside in virtually all post-natal organs and tissues. J Cell Sci 119 (Pt 11):2204-2213. doi: $10.1242 / j$ cs. 02932

94. Najar M, Raicevic G, Boufker HI, Fayyad Kazan H, De Bruyn C, Meuleman N, Bron D, Toungouz M, Lagneaux L (2010) Mesenchymal stromal cells use PGE2 to modulate activation and proliferation of lymphocyte subsets: Combined comparison of adipose tissue, Wharton's Jelly and bone marrow sources. Cell Immunol 264 (2):171-179. doi:10.1016/j.cellimm.2010.06.006

95. Montesinos JJ, Flores-Figueroa E, Castillo-Medina S, Flores-Guzman P, Hernandez-Estevez E, Fajardo-Orduna G, Orozco S, Mayani H (2009) Human mesenchymal stromal cells from adult and neonatal sources: comparative analysis of their morphology, immunophenotype, differentiation patterns and neural protein expression. Cytotherapy 11 (2):163-176. doi:10.1080/14653240802582075

96. Luz-Crawford P, Torres MJ, Noel D, Fernandez A, Toupet K, Alcayaga-Miranda F, Tejedor G, Jorgensen C, Illanes SE, Figueroa FE, Djouad F, Khoury M (2015) The Immunosuppressive Signature of Menstrual Blood Mesenchymal Stem Cells Entails Opposite Effects on Experimental Arthritis and Graft Versus Host Diseases. Stem Cells. doi:10.1002/stem.2244

97. Kaltz N, Funari A, Hippauf S, Delorme B, Noel D, Riminucci M, Jacobs VR, Haupl T, Jorgensen C, Charbord P, Peschel C, Bianco P, Oostendorp RA (2008) In vivo osteoprogenitor potency of human stromal cells from different tissues does not correlate with expression of POU5F1 or its pseudogenes. Stem Cells 26 (9):24192424. doi:10.1634/stemcells.2008-0304

98. Sousa BR, Parreira RC, Fonseca EA, Amaya MJ, Tonelli FM, Lacerda SM, Lalwani P, Santos AK, Gomes KN, Ulrich H, Kihara AH, Resende RR (2014) Human adult stem cells from diverse origins: an overview from multiparametric immunophenotyping to clinical applications. Cytometry A 85 (1):43-77. doi:10.1002/cyto.a.22402

99. De Ugarte DA, Morizono K, Elbarbary A, Alfonso Z, Zuk PA, Zhu M, Dragoo JL, Ashjian P, Thomas B, Benhaim P, Chen I, Fraser J, Hedrick MH (2003) Comparison of multi-lineage cells from human adipose tissue and bone marrow. Cells Tissues Organs 174 (3):101-109. doi:71150 
100. Roche S, Delorme B, Oostendorp RA, Barbet R, Caton D, Noel D, Boumediene K, Papadaki HA, Cousin B, Crozet C, Milhavet O, Casteilla L, Hatzfeld J, Jorgensen C, Charbord P, Lehmann S (2009) Comparative proteomic analysis of human mesenchymal and embryonic stem cells: towards the definition of a mesenchymal stem cell proteomic signature. Proteomics 9 (2):223-232. doi:10.1002/pmic.200800035

101. Sivasubramaniyan K, Lehnen D, Ghazanfari R, Sobiesiak M, Harichandan A, Mortha E, Petkova N, Grimm S, Cerabona F, de Zwart P, Abele H, Aicher WK, Faul C, Kanz L, Buhring HJ (2012) Phenotypic and functional heterogeneity of human bone marrow- and amnion-derived MSC subsets. Ann N Y Acad Sci 1266:94-106. doi:10.1111/j.1749-6632.2012.06551.x

102. Djouad F, Bony C, Haupl T, Uze G, Lahlou N, Louis-Plence P, Apparailly F, Canovas F, Reme T, Sany J, Jorgensen C, Noel D (2005) Transcriptional profiles discriminate bone marrow-derived and synovium-derived mesenchymal stem cells. Arthritis Res Ther 7 (6):R1304-1315. doi:10.1186/ar1827

103. Phinney DG, Sensebe L (2013) Mesenchymal stromal cells: misconceptions and evolving concepts. Cytotherapy 15 (2):140-145. doi:10.1016/j.jcyt.2012.11.005 104. Deuse T, Stubbendorff M, Tang-Quan K, Phillips N, Kay MA, Eiermann T, Phan TT, Volk HD, Reichenspurner H, Robbins RC, Schrepfer S (2011) Immunogenicity and immunomodulatory properties of umbilical cord lining mesenchymal stem cells. Cell Transplant 20 (5):655-667. doi:10.3727/096368910X536473

105. Wegmeyer H, Broske AM, Leddin M, Kuentzer K, Nisslbeck AK, Hupfeld J, Wiechmann K, Kuhlen J, von Schwerin C, Stein C, Knothe S, Funk J, Huss R, Neubauer M (2013) Mesenchymal stromal cell characteristics vary depending on their origin. Stem Cells Dev 22 (19):2606-2618. doi:10.1089/scd.2013.0016

106. Noel D, Caton D, Roche S, Bony C, Lehmann S, Casteilla L, Jorgensen C, Cousin B (2008) Cell specific differences between human adipose-derived and mesenchymal-stromal cells despite similar differentiation potentials. Exp Cell Res 314 (7):1575-1584. doi:10.1016/j.yexcr.2007.12.022

107. Puissant B, Barreau C, Bourin P, Clavel C, Corre J, Bousquet C, Taureau C, Cousin B, Abbal M, Laharrague P, Penicaud L, Casteilla L, Blancher A (2005) Immunomodulatory effect of human adipose tissue-derived adult stem cells: comparison with bone marrow mesenchymal stem cells. $\mathrm{Br} J$ Haematol 129 (1):118129. doi:10.1111/j.1365-2141.2005.05409.x

108. Strioga M, Viswanathan S, Darinskas A, Slaby O, Michalek J (2012) Same or not the same? Comparison of adipose tissue-derived versus bone marrow-derived mesenchymal stem and stromal cells. Stem Cells Dev 21 (14):2724-2752. doi:10.1089/scd.2011.0722

109. Gupta MK, Ajay AK (2015) Fat on sale: role of adipose-derived stem cells as anti-fibrosis agent in regenerative medicine. Stem Cell Res Ther 6:233. doi:10.1186/s13287-015-0246-3

110. Pikula M, Marek-Trzonkowska N, Wardowska A, Renkielska A, Trzonkowski P (2013) Adipose tissue-derived stem cells in clinical applications. Expert Opin Biol Ther 13 (10):1357-1370. doi:10.1517/14712598.2013.823153

111. Lin K, Matsubara $Y$, Masuda $Y$, Togashi K, Ohno T, Tamura T, Toyoshima $Y$, Sugimachi K, Toyoda M, Marc H, Douglas A (2008) Characterization of adipose tissue-derived cells isolated with the Celution system. Cytotherapy 10 (4):417-426. doi:10.1080/14653240801982979 
112. Gimble JM, Guilak F, Bunnell BA (2010) Clinical and preclinical translation of cell-based therapies using adipose tissue-derived cells. Stem Cell Res Ther 1 (2):19. doi:10.1186/scrt19

113. Bailey AM, Kapur S, Katz AJ (2010) Characterization of adipose-derived stem cells: an update. Curr Stem Cell Res Ther 5 (2):95-102

114. Ong WK, Tan CS, Chan KL, Goesantoso GG, Chan XH, Chan E, Yin J, Yeo CR, Khoo CM, So JB, Shabbir A, Toh SA, Han W, Sugii S (2014) Identification of specific cell-surface markers of adipose-derived stem cells from subcutaneous and visceral fat depots. Stem Cell Reports 2 (2):171-179. doi:10.1016/j.stemcr.2014.01.002 115. Bony C, Cren M, Domergue S, Toupet K, Jorgensen C, Noel D (2015) Adipose Mesenchymal Stem Cells Isolated after Manual or Water-jet-Assisted Liposuction Display Similar Properties. Front Immunol 6:655. doi:10.3389/fimmu.2015.00655

116. Bochev I, Elmadjian G, Kyurkchiev D, Tzvetanov L, Altankova I, Tivchev P, Kyurkchiev S (2008) Mesenchymal stem cells from human bone marrow or adipose tissue differently modulate mitogen-stimulated B-cell immunoglobulin production in vitro. Cell Biol Int 32 (4):384-393. doi:10.1016/j.cellbi.2007.12.007

117. Ivanova-Todorova E, Bochev I, Mourdjeva M, Dimitrov R, Bukarev D, Kyurkchiev S, Tivchev P, Altunkova I, Kyurkchiev DS (2009) Adipose tissue-derived mesenchymal stem cells are more potent suppressors of dendritic cells differentiation compared to bone marrow-derived mesenchymal stem cells. Immunol Lett 126 (12):37-42. doi:10.1016/j.imlet.2009.07.010

118. Rehman J, Traktuev D, Li J, Merfeld-Clauss S, Temm-Grove CJ, Bovenkerk JE, Pell CL, Johnstone BH, Considine RV, March KL (2004) Secretion of angiogenic and antiapoptotic factors by human adipose stromal cells. Circulation 109 (10):1292-1298. doi:10.1161/01.CIR.0000121425.42966.F1

119. Kim WS, Park BS, Kim HK, Park JS, Kim KJ, Choi JS, Chung SJ, Kim DD, Sung $\mathrm{JH}$ (2008) Evidence supporting antioxidant action of adipose-derived stem cells: protection of human dermal fibroblasts from oxidative stress. J Dermatol Sci 49 (2):133-142. doi:10.1016/j.jdermsci.2007.08.004

120. Kim WS, Park BS, Sung JH (2009) The wound-healing and antioxidant effects of adipose-derived stem cells. Expert Opin Biol Ther 9 (7):879-887. doi:10.1517/14712590903039684

121. Chang $C$ (2014) Unmet needs in the treatment of autoimmunity: from aspirin to stem cells. Autoimmun Rev 13 (4-5):331-346. doi:10.1016/j.autrev.2014.01.052

122. Nie Y, Lau C, Lie A, Chan G, Mok M (2010) Defective phenotype of mesenchymal stem cells in patients with systemic lupus erythematosus. Lupus 19 (7):850-859. doi:10.1177/0961203309361482

123. Kastrinaki MC, Sidiropoulos $P$, Roche $S$, Ringe J, Lehmann S, Kritikos H, Vlahava VM, Delorme B, Eliopoulos GD, Jorgensen C, Charbord P, Haupl T, Boumpas DT, Papadaki HA (2008) Functional, molecular and proteomic characterisation of bone marrow mesenchymal stem cells in rheumatoid arthritis. Ann Rheum Dis 67 (6):741-749. doi:10.1136/ard.2007.076174

124. Cipriani P, Di Benedetto P, Ruscitti $P$, Campese AF, Liakouli V, Carubbi F, Pantano I, Berardicurt O, Screpanti I, Giacomelli R (2014) Impaired endotheliummesenchymal stem cells cross-talk in systemic sclerosis: a link between vascular and fibrotic features. Arthritis Res Ther 16 (5):442. doi:10.1186/s13075-014-0442-z 125. Cipriani P, Marrelli A, Benedetto PD, Liakouli V, Carubbi F, Ruscitti P, Alvaro S, Pantano I, Campese AF, Grazioli P, Screpanti I, Giacomelli R (2013) Scleroderma Mesenchymal Stem Cells display a different phenotype from healthy controls; 
implications for regenerative medicine. Angiogenesis 16 (3):595-607. doi:10.1007/s10456-013-9338-9

126. Orciani M, Svegliati S, Gorbi S, Spadoni T, Lazzarini R, Regoli F, Di Primio R, Gabrielli A (2013) Alterations of ROS pathways in scleroderma begin at stem cell level. J Biol Regul Homeost Agents 27 (1):211-224

127. Bartholomew A, Patil S, Mackay A, Nelson M, Buyaner D, Hardy W, Mosca J, Sturgeon C, Siatskas M, Mahmud N, Ferrer K, Deans R, Moseley A, Hoffman R, Devine SM (2001) Baboon mesenchymal stem cells can be genetically modified to secrete human erythropoietin in vivo. Hum Gene Ther 12 (12):1527-1541. doi:10.1089/10430340152480258

128. Zappia E, Casazza S, Pedemonte E, Benvenuto F, Bonanni I, Gerdoni E, Giunti D, Ceravolo A, Cazzanti F, Frassoni F, Mancardi G, Uccelli A (2005) Mesenchymal stem cells ameliorate experimental autoimmune encephalomyelitis inducing $\mathrm{T}$-cell anergy. Blood 106 (5):1755-1761. doi:10.1182/blood-2005-04-1496

129. Augello A, Tasso R, Negrini SM, Cancedda R, Pennesi G (2007) Cell therapy using allogeneic bone marrow mesenchymal stem cells prevents tissue damage in collagen-induced arthritis. Arthritis Rheum 56 (4):1175-1186. doi:10.1002/art.22511

130. Bouffi C, Bony C, Jorgensen C, Noel D (2011) Skin fibroblasts are potent suppressors of inflammation in experimental arthritis. Ann Rheum Dis 70 (9):16711676. doi:10.1136/ard.2010.143297

131. Zhou K, Zhang H, Jin O, Feng X, Yao G, Hou Y, Sun L (2008) Transplantation of human bone marrow mesenchymal stem cell ameliorates the autoimmune pathogenesis in MRL/lpr mice. Cell Mol Immunol 5 (6):417-424. doi:10.1038/cmi.2008.52

132. Ringden $O$, Uzunel $M$, Rasmusson I, Remberger $M$, Sundberg $B$, Lonnies $H$, Marschall HU, Dlugosz A, Szakos A, Hassan Z, Omazic B, Aschan J, Barkholt L, Le Blanc K (2006) Mesenchymal stem cells for treatment of therapy-resistant graftversus-host disease. Transplantation $81 \quad$ (10):1390-1397. doi:10.1097/01.tp.0000214462.63943.14

133. Lee RH, Seo MJ, Reger RL, Spees JL, Pulin AA, Olson SD, Prockop DJ (2006) Multipotent stromal cells from human marrow home to and promote repair of pancreatic islets and renal glomeruli in diabetic NOD/scid mice. Proc Natl Acad Sci U S A 103 (46):17438-17443. doi:10.1073/pnas.0608249103

134. Polchert D, Sobinsky J, Douglas G, Kidd M, Moadsiri A, Reina E, Genrich K, Mehrotra S, Setty S, Smith B, Bartholomew A (2008) IFN-gamma activation of mesenchymal stem cells for treatment and prevention of graft versus host disease. Eur J Immunol 38 (6):1745-1755. doi:10.1002/eji.200738129

135. Borchers AT, Leibushor N, Naguwa SM, Cheema GS, Shoenfeld Y, Gershwin ME (2012) Lupus nephritis: a critical review. Autoimmun Rev 12 (2):174-194. doi:10.1016/j.autrev.2012.08.018

136. Cervera R, Doria A, Amoura Z, Khamashta M, Schneider M, Guillemin F, Maurel F, Garofano A, Roset M, Perna A, Murray M, Schmitt C, Boucot I (2014) Patterns of systemic lupus erythematosus expression in Europe. Autoimmun Rev 13 (6):621-629. doi:10.1016/j.autrev.2013.11.007

137. Riboldi P, Gerosa M, Luzzana C, Catelli L (2002) Cardiac involvement in systemic autoimmune diseases. Clin Rev Allergy Immunol 23 (3):247-261. doi:10.1385/CRIAI:23:3:247

138. Sitia S, Atzeni F, Sarzi-Puttini P, Di Bello V, Tomasoni L, Delfino L, AntoniniCanterin F, Di Salvo G, De Gennaro Colonna V, La Carrubba S, Carerj S, Turiel M 
(2009) Cardiovascular involvement in systemic autoimmune diseases. Autoimmun Rev 8 (4):281-286. doi:10.1016/j.autrev.2008.08.004

139. Wu GC, Liu HR, Leng RX, Li XP, Li XM, Pan HF, Ye DQ (2016) Subclinical atherosclerosis in patients with systemic lupus erythematosus: A systemic review and meta-analysis. Autoimmun Rev 15 (1):22-37. doi:10.1016/j.autrev.2015.10.002 140. Qian J, Wang Y, Huang C, Yang X, Zhao J, Wang Q, Tian Z, Li M, Zeng X (2016) Survival and prognostic factors of systemic lupus erythematosus-associated pulmonary arterial hypertension: A PRISMA-compliant systematic review and metaanalysis. Autoimmun Rev 15 (3):250-257. doi:10.1016/j.autrev.2015.11.012

141. Sarbu N, Alobeidi F, Toledano P, Espinosa G, Giles I, Rahman A, Yousry T, Capurro S, Jager R, Cervera R, Bargallo N (2015) Brain abnormalities in newly diagnosed neuropsychiatric lupus: systematic MRI approach and correlation with clinical and laboratory data in a large multicenter cohort. Autoimmun Rev 14 (2):153159. doi:10.1016/j.autrev.2014.11.001

142. Roccatello D, Sciascia S, Baldovino S, Rossi D, Alpa M, Naretto C, Di Simone D, Simoncini M, Menegatti E (2015) A 4-year observation in lupus nephritis patients treated with an intensified B-lymphocyte depletion without immunosuppressive maintenance treatment-Clinical response compared to literature and immunological re-assessment. Autoimmun Rev $14 \quad$ (12):1123-1130. doi:10.1016/j.autrev.2015.07.017

143. Jeltsch-David H, Muller S (2014) Neuropsychiatric systemic lupus erythematosus and cognitive dysfunction: the MRL-Ipr mouse strain as a model. Autoimmun Rev 13 (9):963-973. doi:10.1016/j.autrev.2014.08.015

144. Gatto M, Zen M, Ghirardello A, Bettio S, Bassi N, laccarino L, Punzi L, Doria A (2013) Emerging and critical issues in the pathogenesis of lupus. Autoimmun Rev 12 (4):523-536. doi:10.1016/j.autrev.2012.09.003

145. Sawla P, Hossain A, Hahn BH, Singh RP (2012) Regulatory T cells in systemic lupus erythematosus (SLE); role of peptide tolerance. Autoimmun Rev 11 (9):611614. doi:10.1016/j.autrev.2011.09.008

146. Ruiz-Arruza I, Barbosa C, Ugarte A, Ruiz-Irastorza G (2015) Comparison of high versus low-medium prednisone doses for the treatment of systemic lupus erythematosus patients with high activity at diagnosis. Autoimmun Rev 14 (10):875879. doi:10.1016/j.autrev.2015.05.011

147. Hannah J, Casian A, D'Cruz D (2016) Tacrolimus use in lupus nephritis: A systematic review and meta-analysis. Autoimmun Rev 15 (1):93-101. doi:10.1016/j.autrev.2015.09.006

148. Frieri M, Stampfl H (2016) Systemic lupus erythematosus and atherosclerosis: Review of the literature. Autoimmun Rev 15 (1):16-21. doi:10.1016/j.autrev.2015.08.007

149. Cohen Y, Nagler A (2004) Treatment of refractory autoimmune diseases with ablative immunotherapy. Autoimmun Rev 3 (2):21-29. doi:10.1016/S15689972(03)00083-1

150. Sciascia S, Ceberio L, Garcia-Fernandez C, Roccatello D, Karim Y, Cuadrado MJ (2012) Systemic lupus erythematosus and infections: clinical importance of conventional and upcoming biomarkers. Autoimmun Rev 12 (2):157-163. doi:10.1016/j.autrev.2012.03.009

151. Davies RJ, Sangle SR, Jordan NP, Aslam L, Lewis MJ, Wedgwood R, D'Cruz DP (2013) Rituximab in the treatment of resistant lupus nephritis: therapy failure in rapidly progressive crescentic lupus nephritis. Lupus 22 (6):574-582. doi:10.1177/0961203313483376 
152. Kamal A, Khamashta M (2014) The efficacy of novel B cell biologics as the future of SLE treatment: a review. Autoimmun Rev 13 (11):1094-1101. doi:10.1016/j.autrev.2014.08.020

153. Furie R, Petri M, Zamani O, Cervera R, Wallace DJ, Tegzova D, SanchezGuerrero J, Schwarting A, Merrill JT, Chatham WW, Stohl W, Ginzler EM, Hough DR, Zhong ZJ, Freimuth W, van Vollenhoven RF, Group B-S (2011) A phase III, randomized, placebo-controlled study of belimumab, a monoclonal antibody that inhibits B lymphocyte stimulator, in patients with systemic lupus erythematosus. Arthritis Rheum 63 (12):3918-3930. doi:10.1002/art.30613

154. Liao J, Chang C, Wu H, Lu Q (2015) Cell-based therapies for systemic lupus erythematosus. Autoimmun Rev 14 (1):43-48. doi:10.1016/j.autrev.2014.10.001

155. Papadaki HA, Boumpas DT, Gibson FM, Jayne DR, Axford JS, Gordon-Smith EC, Marsh JC, Eliopoulos GD (2001) Increased apoptosis of bone marrow CD34(+) cells and impaired function of bone marrow stromal cells in patients with systemic lupus erythematosus. $\mathrm{Br} \mathrm{J}$ Haematol 115 (1):167-174

156. Sun L, Akiyama K, Zhang H, Yamaza T, Hou Y, Zhao S, Xu T, Le A, Shi S (2009) Mesenchymal stem cell transplantation reverses multiorgan dysfunction in systemic lupus erythematosus mice and humans. Stem Cells 27 (6):1421-1432. doi:10.1002/stem.68

157. Sun LY, Zhang HY, Feng XB, Hou YY, Lu LW, Fan LM (2007) Abnormality of bone marrow-derived mesenchymal stem cells in patients with systemic lupus erythematosus. Lupus 16 (2):121-128

158. Tang Y, Ma X, Zhang H, Gu Z, Hou Y, Gilkeson GS, Lu L, Zeng X, Sun L (2012) Gene expression profile reveals abnormalities of multiple signaling pathways in mesenchymal stem cell derived from patients with systemic lupus erythematosus. Clin Dev Immunol 2012:826182. doi:10.1155/2012/826182

159. Gu Z, Cao X, Jiang J, Li L, Da Z, Liu H, Cheng C (2012) Upregulation of p16INK4A promotes cellular senescence of bone marrow-derived mesenchymal stem cells from systemic lupus erythematosus patients. Cell Signal 24 (12):23072314. doi:10.1016/j.cellsig.2012.07.012

160. Gu Z, Tan W, Feng G, Meng Y, Shen B, Liu H, Cheng C (2014) Wnt/betacatenin signaling mediates the senescence of bone marrow-mesenchymal stem cells from systemic lupus erythematosus patients through the p53/p21 pathway. Mol Cell Biochem 387 (1-2):27-37. doi:10.1007/s11010-013-1866-5

161. Li X, Liu L, Meng D, Wang D, Zhang J, Shi D, Liu H, Xu H, Lu L, Sun L (2012) Enhanced apoptosis and senescence of bone-marrow-derived mesenchymal stem cells in patients with systemic lupus erythematosus. Stem Cells Dev 21 (13):23872394. doi:10.1089/scd.2011.0447

162. Gu F, Molano I, Ruiz P, Sun L, Gilkeson GS (2012) Differential effect of allogeneic versus syngeneic mesenchymal stem cell transplantation in MRL/lpr and (NZB/NZW)F1 mice. Clin Immunol 145 (2):142-152. doi:10.1016/j.clim.2012.08.012 163. Collins E, Gu F, Qi M, Molano I, Ruiz P, Sun L, Gilkeson GS (2014) Differential efficacy of human mesenchymal stem cells based on source of origin. J Immunol 193 (9):4381-4390. doi:10.4049/jimmunol.1401636

164. Zhou K, Zhang H, Jin O, Feng X, Yao G, Hou Y, Sun L (2008) Transplantation of human bone marrow mesenchymal stem cell ameliorates the autoimmune pathogenesis in MRL/lpr mice. Cell Mol Immunol 5 (6):417-424. doi:10.1038/cmi.2008.52

165. Ma X, Che N, Gu Z, Huang J, Wang D, Liang J, Hou Y, Gilkeson G, Lu L, Sun L (2013) Allogenic mesenchymal stem cell transplantation ameliorates nephritis in 
lupus mice via inhibition of B-cell activation. Cell Transplant 22 (12):2279-2290. doi:10.3727/096368912X658692

166. Youd M, Blickarz C, Woodworth L, Touzjian T, Edling A, Tedstone J, Ruzek M, Tubo R, Kaplan J, Lodie T (2010) Allogeneic mesenchymal stem cells do not protect NZBxNZW F1 mice from developing lupus disease. Clin Exp Immunol 161 (1):176186. doi:10.1111/j.1365-2249.2010.04158.x

167. Schena F, Gambini C, Gregorio A, Mosconi M, Reverberi D, Gattorno M, Casazza S, Uccelli A, Moretta L, Martini A, Traggiai E (2010) Interferon-gammadependent inhibition of B cell activation by bone marrow-derived mesenchymal stem cells in a murine model of systemic lupus erythematosus. Arthritis Rheum 62 (9):2776-2786. doi:10.1002/art.27560

168. Park MJ, Kwok SK, Lee SH, Kim EK, Park SH, Cho ML (2015) Adipose tissuederived mesenchymal stem cells induce expansion of interleukin-10-producing regulatory $B$ cells and ameliorate autoimmunity in a murine model of systemic lupus erythematosus. Cell Transplant 24 (11):2367-2377. doi:10.3727/096368914X685645 169. Choi EW, Shin IS, Song JW, Yun TW, Yang J, Choi KS, Seong JK (2015) Transplantation of Adipose Tissue-Derived Mesenchymal Stem Cells Prevents the Development of Lupus Dermatitis. Stem Cells Dev 24 (17):2041-2051. doi:10.1089/scd.2015.0021

170. Choi EW, Lee HW, Shin S, Park JH, Yun TW, Youn HY, Kim SJ (2015) Comparative efficacies of long-term serial transplantation of syngeneic, allogeneic, xenogeneic, or CTLA4Ig overproducing xenogeneic adipose tissue-derived mesenchymal stem cells on murine systemic lupus erythematosus. Cell Transplant. doi:10.3727/096368915X689442

171. Choi EW, Shin IS, Park SY, Park JH, Kim JS, Yoon EJ, Kang SK, Ra JC, Hong $\mathrm{SH}$ (2012) Reversal of serologic, immunologic, and histologic dysfunction in mice with systemic lupus erythematosus by long-term serial adipose tissue-derived mesenchymal stem cell transplantation. Arthritis Rheum 64 (1):243-253. doi:10.1002/art.33313

172. Gu Z, Akiyama K, Ma X, Zhang H, Feng X, Yao G, Hou Y, Lu L, Gilkeson GS, Silver RM, Zeng X, Shi S, Sun L (2010) Transplantation of umbilical cord mesenchymal stem cells alleviates lupus nephritis in MRL/pr mice. Lupus 19 (13):1502-1514. doi:10.1177/0961203310373782

173. Chang JW, Hung SP, Wu HH, Wu WM, Yang AH, Tsai HL, Yang LY, Lee OK (2011) Therapeutic effects of umbilical cord blood-derived mesenchymal stem cell transplantation in experimental lupus nephritis. Cell Transplant 20 (2):245-257. doi:10.3727/096368910X520056

174. Carrion F, Nova E, Ruiz C, Diaz F, Inostroza C, Rojo D, Monckeberg G, Figueroa FE (2010) Autologous mesenchymal stem cell treatment increased $T$ regulatory cells with no effect on disease activity in two systemic lupus erythematosus patients. Lupus 19 (3):317-322. doi:10.1177/0961203309348983

175. Liang J, Zhang H, Hua B, Wang H, Lu L, Shi S, Hou Y, Zeng X, Gilkeson GS, Sun $L$ (2010) Allogenic mesenchymal stem cells transplantation in refractory systemic lupus erythematosus: a pilot clinical study. Ann Rheum Dis 69 (8):14231429. doi:10.1136/ard.2009.123463

176. Sun L, Wang D, Liang J, Zhang H, Feng X, Wang H, Hua B, Liu B, Ye S, Hu X, Xu W, Zeng X, Hou Y, Gilkeson GS, Silver RM, Lu L, Shi S (2010) Umbilical cord mesenchymal stem cell transplantation in severe and refractory systemic lupus erythematosus. Arthritis Rheum 62 (8):2467-2475. doi:10.1002/art.27548 
177. Li X, Wang D, Liang J, Zhang H, Sun L (2013) Mesenchymal SCT ameliorates refractory cytopenia in patients with systemic lupus erythematosus. Bone Marrow Transplant 48 (4):544-550. doi:10.1038/bmt.2012.184

178. Liang J, Gu F, Wang H, Hua B, Hou Y, Shi S, Lu L, Sun L (2010) Mesenchymal stem cell transplantation for diffuse alveolar hemorrhage in SLE. Nat Rev Rheumatol 6 (8):486-489. doi:10.1038/nrrheum.2010.80

179. Shi D, Wang D, Li X, Zhang H, Che N, Lu Z, Sun L (2012) Allogeneic transplantation of umbilical cord-derived mesenchymal stem cells for diffuse alveolar hemorrhage in systemic lupus erythematosus. Clin Rheumatol 31 (5):841-846. doi:10.1007/s10067-012-1943-2

180. Wang D, Zhang H, Liang J, Li X, Feng X, Wang H, Hua B, Liu B, Lu L, Gilkeson GS, Silver RM, Chen W, Shi S, Sun L (2013) Allogeneic mesenchymal stem cell transplantation in severe and refractory systemic lupus erythematosus: 4 years of experience. Cell Transplant 22 (12):2267-2277. doi:10.3727/096368911X582769

181. Gu F, Wang D, Zhang H, Feng X, Gilkeson GS, Shi S, Sun L (2014) Allogeneic mesenchymal stem cell transplantation for lupus nephritis patients refractory to conventional therapy. Clin Rheumatol 33 (11):1611-1619. doi:10.1007/s10067-0142754-4

182. Wang D, Li J, Zhang Y, Zhang M, Chen J, Li X, Hu X, Jiang S, Shi S, Sun L (2014) Umbilical cord mesenchymal stem cell transplantation in active and refractory systemic lupus erythematosus: a multicenter clinical study. Arthritis Res Ther 16 (2):R79. doi:10.1186/ar4520

183. Modena V, Bianchi G, Roccatello D (2013) Cost-effectiveness of biologic treatment for rheumatoid arthritis in clinical practice: an achievable target? Autoimmun Rev 12 (8):835-838. doi:10.1016/j.autrev.2012.11.009

184. Epis OM, Giacomelli L, Deidda S, Bruschi E (2013) Tight control applied to the biological therapy of rheumatoid arthritis. Autoimmun Rev 12 (8):839-841. doi:10.1016/j.autrev.2012.11.010

185. Dimitroulas T, Nikas SN, Trontzas P, Kitas GD (2013) Biologic therapies and systemic bone loss in rheumatoid arthritis. Autoimmun Rev 12 (10):958-966. doi:10.1016/j.autrev.2013.03.015

186. Cutolo M, Nadler SG (2013) Advances in CTLA-4-Ig-mediated modulation of inflammatory cell and immune response activation in rheumatoid arthritis. Autoimmun Rev 12 (7):758-767. doi:10.1016/j.autrev.2013.01.001

187. Chen B, Hu J, Liao L, Sun Z, Han Q, Song Z, Zhao RC (2010) Flk-1+ mesenchymal stem cells aggravate collagen-induced arthritis by up-regulating interleukin-6. Clin Exp Immunol 159 (3):292-302. doi:10.1111/j.13652249.2009.04069.x

188. Djouad F, Fritz V, Apparailly F, Louis-Plence P, Bony C, Sany J, Jorgensen C, Noel D (2005) Reversal of the immunosuppressive properties of mesenchymal stem cells by tumor necrosis factor alpha in collagen-induced arthritis. Arthritis Rheum 52 (5):1595-1603. doi:10.1002/art.21012

189. Liu Y, Mu R, Wang S, Long L, Liu X, Li R, Sun J, Guo J, Zhang X, Guo J, Yu P, Li C, Liu X, Huang Z, Wang D, Li H, Gu Z, Liu B, Li Z (2010) Therapeutic potential of human umbilical cord mesenchymal stem cells in the treatment of rheumatoid arthritis. Arthritis Res Ther 12 (6):R210. doi:10.1186/ar3187

190. Gonzalez MA, Gonzalez-Rey E, Rico L, Buscher D, Delgado M (2009) Treatment of experimental arthritis by inducing immune tolerance with human adipose-derived mesenchymal stem cells. Arthritis Rheum 60 (4):1006-1019. doi:10.1002/art.24405 
191. Wang L, Wang L, Cong X, Liu G, Zhou J, Bai B, Li Y, Bai W, Li M, Ji H, Zhu D, Wu M, Liu Y (2013) Human umbilical cord mesenchymal stem cell therapy for patients with active rheumatoid arthritis: safety and efficacy. Stem Cells Dev 22 (24):3192-3202. doi:10.1089/scd.2013.0023

192. Wang L, Zhang Y, Li H, Hong J, Chen X, Li M, Bai W, Wang J, Liu Y, Wu M (2016) Clinical Observation of Employment of Umbilical Cord Derived Mesenchymal Stem Cell for Juvenile Idiopathic Arthritis Therapy. Stem Cells Int 2016:9165267. doi:10.1155/2016/9165267

193. Khalili S, Faustman DL, Liu Y, Sumita Y, Blank D, Peterson A, Kodama S, Tran SD (2014) Treatment for salivary gland hypofunction at both initial and advanced stages of Sjogren-like disease: a comparative study of bone marrow therapy versus spleen cell therapy with a 1-year monitoring period. Cytotherapy 16 (3):412-423. doi:10.1016/j.jcyt.2013.10.006

194. Xu J, Wang D, Liu D, Fan Z, Zhang H, Liu O, Ding G, Gao R, Zhang C, Ding Y, Bromberg JS, Chen W, Sun L, Wang S (2012) Allogeneic mesenchymal stem cell treatment alleviates experimental and clinical Sjogren syndrome. Blood 120 (15):3142-3151. doi:10.1182/blood-2011-11-391144

195. Voswinkel J, Francois S, Simon JM, Benderitter M, Gorin NC, Mohty M, Fouillard L, Chapel A (2013) Use of mesenchymal stem cells (MSC) in chronic inflammatory fistulizing and fibrotic diseases: a comprehensive review. Clin Rev Allergy Immunol 45 (2):180-192. doi:10.1007/s12016-012-8347-6

196. Cho YB, Lee WY, Park KJ, Kim M, Yoo HW, Yu CS (2013) Autologous adipose tissue-derived stem cells for the treatment of Crohn's fistula: a phase I clinical study. Cell Transplant 22 (2):279-285. doi:10.3727/096368912X656045

197. Duijvestein M, Vos AC, Roelofs $H$, Wildenberg ME, Wendrich BB, Verspaget HW, Kooy-Winkelaar EM, Koning F, Zwaginga JJ, Fidder HH, Verhaar AP, Fibbe WE, van den Brink GR, Hommes DW (2010) Autologous bone marrow-derived mesenchymal stromal cell treatment for refractory luminal Crohn's disease: results of a phase I study. Gut 59 (12):1662-1669. doi:10.1136/gut.2010.215152

198. de la Portilla F, Alba F, Garcia-Olmo D, Herrerias JM, Gonzalez FX, Galindo A (2013) Expanded allogeneic adipose-derived stem cells (eASCs) for the treatment of complex perianal fistula in Crohn's disease: results from a multicenter phase I/Ila clinical trial. Int J Colorectal Dis 28 (3):313-323. doi:10.1007/s00384-012-1581-9

199. Gregorini M, Maccario R, Avanzini MA, Corradetti V, Moretta A, Libetta C, Esposito P, Bosio F, Dal Canton A, Rampino T (2013) Antineutrophil cytoplasmic antibody-associated renal vasculitis treated with autologous mesenchymal stromal cells: evaluation of the contribution of immune-mediated mechanisms. Mayo Clin Proc 88 (10):1174-1179. doi:10.1016/j.mayocp.2013.06.021

200. Davatchi F, Nikbin B, Shams H, Sadeghi Abdollahi B, Mohyeddin M, Shahram F (2013) Mesenchymal stem cell therapy unable to rescue the vision from advanced Behcet's disease retinal vasculitis: report of three patients. Int $\mathrm{J}$ Rheum Dis 16 (2):139-147. doi:10.1111/1756-185X.12068

201. Lablanche S, Borot S, Wojtusciszyn A, Bayle F, Tetaz R, Badet L, Thivolet C, Morelon E, Frimat L, Penfornis A, Kessler L, Brault C, Colin C, Tauveron I, Bosco D, Berney T, Benhamou PY, Network G (2015) Five-Year Metabolic, Functional, and Safety Results of Patients With Type 1 Diabetes Transplanted With Allogenic Islets Within the Swiss-French GRAGIL Network. Diabetes Care 38 (9):1714-1722. doi:10.2337/dc15-0094

202. Boumaza I, Srinivasan S, Witt WT, Feghali-Bostwick C, Dai Y, Garcia-Ocana A, Feili-Hariri M (2009) Autologous bone marrow-derived rat mesenchymal stem cells 
promote PDX-1 and insulin expression in the islets, alter T cell cytokine pattern and preserve regulatory $\mathrm{T}$ cells in the periphery and induce sustained normoglycemia. $\mathrm{J}$ Autoimmun 32 (1):33-42. doi:10.1016/j.jaut.2008.10.004

203. Xin Y, Jiang X, Wang Y, Su X, Sun M, Zhang L, Tan Y, Wintergerst KA, Li Y, Li $Y$ (2016) Insulin-Producing Cells Differentiated from Human Bone Marrow Mesenchymal Stem Cells In Vitro Ameliorate Streptozotocin-Induced Diabetic Hyperglycemia. PLoS One 11 (1):e0145838. doi:10.1371/journal.pone.0145838

204. Gerdoni E, Gallo B, Casazza S, Musio S, Bonanni I, Pedemonte E, Mantegazza R, Frassoni F, Mancardi G, Pedotti R, Uccelli A (2007) Mesenchymal stem cells effectively modulate pathogenic immune response in experimental autoimmune encephalomyelitis. Ann Neurol 61 (3):219-227. doi:10.1002/ana.21076

205. Kassis I, Grigoriadis N, Gowda-Kurkalli B, Mizrachi-Kol R, Ben-Hur T, Slavin S, Abramsky O, Karussis D (2008) Neuroprotection and immunomodulation with mesenchymal stem cells in chronic experimental autoimmune encephalomyelitis. Arch Neurol 65 (6):753-761. doi:10.1001/archneur.65.6.753

206. Wang D, Li SP, Fu JS, Bai L, Guo L (2016) Resveratrol augments therapeutic efficiency of mouse bone marrow mesenchymal stem cell-based therapy in experimental autoimmune encephalomyelitis. Int $J$ Dev Neurosci 49:60-66. doi:10.1016/j.ijdevneu.2016.01.005

207. Connick P, Kolappan M, Crawley C, Webber DJ, Patani R, Michell AW, Du MQ, Luan SL, Altmann DR, Thompson AJ, Compston A, Scott MA, Miller DH, Chandran S (2012) Autologous mesenchymal stem cells for the treatment of secondary progressive multiple sclerosis: an open-label phase 2a proof-of-concept study. Lancet Neurol 11 (2):150-156. doi:10.1016/S1474-4422(11)70305-2

208. Lublin FD, Bowen JD, Huddlestone J, Kremenchutzky M, Carpenter A, Corboy JR, Freedman MS, Krupp L, Paulo C, Hariri RJ, Fischkoff SA (2014) Human placenta-derived cells (PDA-001) for the treatment of adults with multiple sclerosis: a randomized, placebo-controlled, multiple-dose study. Mult Scler Relat Disord 3 (6):696-704. doi:10.1016/j.msard.2014.08.002

209. Llufriu S, Sepulveda M, Blanco Y, Marin P, Moreno B, Berenguer J, Gabilondo I, Martinez-Heras E, Sola-Valls N, Arnaiz JA, Andreu EJ, Fernandez B, Bullich S, Sanchez-Dalmau B, Graus F, Villoslada P, Saiz A (2014) Randomized placebocontrolled phase II trial of autologous mesenchymal stem cells in multiple sclerosis. PLoS One 9 (12):e113936. doi:10.1371/journal.pone.0113936

210. Li JF, Zhang DJ, Geng T, Chen L, Huang H, Yin HL, Zhang YZ, Lou JY, Cao B, Wang YL (2014) The potential of human umbilical cord-derived mesenchymal stem cells as a novel cellular therapy for multiple sclerosis. Cell Transplant 23 Suppl $1: S 113-122$. doi:10.3727/096368914X685005

211. Le Blanc K, Frassoni F, Ball L, Locatelli F, Roelofs $H$, Lewis I, Lanino $E$, Sundberg B, Bernardo ME, Remberger M, Dini G, Egeler RM, Bacigalupo A, Fibbe W, Ringden O, Developmental Committee of the European Group for B, Marrow T (2008) Mesenchymal stem cells for treatment of steroid-resistant, severe, acute graftversus-host disease: a phase II study. Lancet 371 (9624):1579-1586. doi:10.1016/S0140-6736(08)60690-X

212. Yanez R, Lamana ML, Garcia-Castro J, Colmenero I, Ramirez M, Bueren JA (2006) Adipose tissue-derived mesenchymal stem cells have in vivo immunosuppressive properties applicable for the control of the graft-versus-host disease. Stem Cells 24 (11):2582-2591. doi:10.1634/stemcells.2006-0228

213. Fang B, Song Y, Liao L, Zhang Y, Zhao RC (2007) Favorable response to human adipose tissue-derived mesenchymal stem cells in steroid-refractory acute 
graft-versus-host disease. Transplant Proc 39 (10):3358-3362. doi:10.1016/j.transproceed.2007.08.103

214. Kong QF, Sun B, Wang GY, Zhai DX, Mu LL, Wang DD, Wang JH, Li R, Li HL (2009) BM stromal cells ameliorate experimental autoimmune myasthenia gravis by altering the balance of Th cells through the secretion of IDO. Eur J Immunol 39 (3):800-809. doi:10.1002/eji.200838729

215. Kong QF, Sun B, Bai SS, Zhai DX, Wang GY, Liu YM, Zhang SJ, Li R, Zhao W, Sun YY, Li N, Wang Q, Peng HS, Jin LH, Li HL (2009) Administration of bone marrow stromal cells ameliorates experimental autoimmune myasthenia gravis by altering the balance of Th1/Th2/Th17/Treg cell subsets through the secretion of TGFbeta. J Neuroimmunol 207 (1-2):83-91. doi:10.1016/j.jneuroim.2008.12.005

216. Yu J, Zheng C, Ren X, Li J, Liu M, Zhang L, Liang L, Du W, Han ZC (2010) Intravenous administration of bone marrow mesenchymal stem cells benefits experimental autoimmune myasthenia gravis mice through an immunomodulatory action. Scand J Immunol 72 (3):242-249. doi:10.1111/j.1365-3083.2010.02445.x

217. Tiev KP, Cabane J (2011) Digestive tract involvement in systemic sclerosis. Autoimmun Rev 11 (1):68-73. doi:10.1016/j.autrev.2010.06.002

218. Chizzolini C, Brembilla NC, Montanari E, Truchetet ME (2011) Fibrosis and immune dysregulation in systemic sclerosis. Autoimmun Rev 10 (5):276-281. doi:10.1016/j.autrev.2010.09.016

219. Almeida I, Faria R, Vita P, Vasconcelos C (2011) Systemic sclerosis refractory disease: from the skin to the heart. Autoimmun Rev 10 (11):693-701. doi:10.1016/j.autrev.2011.04.025

220. Galluccio F, Matucci-Cerinic M (2011) Two faces of the same coin: Raynaud phenomenon and digital ulcers in systemic sclerosis. Autoimmun Rev 10 (5):241-243. doi:10.1016/j.autrev.2010.09.008

221. Guiducci S, Giacomelli R, Cerinic MM (2007) Vascular complications of scleroderma. Autoimmun Rev 6 (8):520-523. doi:10.1016/j.autrev.2006.12.006

222. Lambova S, Muller-Ladner $U$ (2010) Pulmonary arterial hypertension in systemic sclerosis. Autoimmun Rev 9 (11):761-770. doi:10.1016/j.autrev.2010.06.006 223. Chora I, Guiducci S, Manetti M, Romano E, Mazzotta C, Bellando-Randone S, lbba-Manneschi L, Matucci-Cerinic M, Soares R (2015) Vascular biomarkers and correlation with peripheral vasculopathy in systemic sclerosis. Autoimmun Rev 14 (4):314-322. doi:10.1016/j.autrev.2014.12.001

224. Nussinovitch $U$, Shoenfeld $Y$ (2011) Atherosclerosis and macrovascular involvement in systemic sclerosis: myth or reality. Autoimmun Rev 10 (5):259-266. doi:10.1016/j.autrev.2010.09.014

225. Baraut J, Michel L, Verrecchia F, Farge D (2010) Relationship between cytokine profiles and clinical outcomes in patients with systemic sclerosis. Autoimmun Rev 10 (2):65-73. doi:10.1016/j.autrev.2010.08.003

226. Bosello S, De Luca G, Tolusso B, Lama G, Angelucci C, Sica G, Ferraccioli G (2011) B cells in systemic sclerosis: a possible target for therapy. Autoimmun Rev 10 (10):624-630. doi:10.1016/j.autrev.2011.04.013

227. Mehra S, Walker J, Patterson K, Fritzler MJ (2013) Autoantibodies in systemic sclerosis. Autoimmun Rev 12 (3):340-354. doi:10.1016/j.autrev.2012.05.011

228. Czompoly T, Simon D, Czirjak L, Nemeth P (2009) Anti-topoisomerase I autoantibodies in systemic sclerosis. Autoimmun Rev 8 (8):692-696. doi:10.1016/j.autrev.2009.02.018 
229. Perosa F, Prete M, Di Lernia G, Ostuni C, Favoino E, Valentini G (2016) Anticentromere protein A antibodies in systemic sclerosis: Significance and origin. Autoimmun Rev 15 (1):102-109. doi:10.1016/j.autrev.2015.10.001

230. Cavazzana I, Ceribelli A, Airo P, Zingarelli S, Tincani A, Franceschini F (2009) Anti-RNA polymerase III antibodies: a marker of systemic sclerosis with rapid onset and skin thickening progression. Autoimmun Rev 8 (7):580-584. doi:10.1016/j.autrev.2009.02.002

231. Hachulla E, Launay D (2011) Diagnosis and classification of systemic sclerosis. Clin Rev Allergy Immunol 40 (2):78-83. doi:10.1007/s12016-010-8198-y

232. Almeida C, Almeida I, Vasconcelos C (2015) Quality of life in systemic sclerosis. Autoimmun Rev 14 (12):1087-1096. doi:10.1016/j.autrev.2015.07.012

233. Bruni C, Raja J, Denton CP, Matucci-Cerinic M (2015) The clinical relevance of sexual dysfunction in systemic sclerosis. Autoimmun Rev 14 (12):1111-1115. doi:10.1016/j.autrev.2015.07.016

234. Wells AU, Steen V, Valentini G (2009) Pulmonary complications: one of the most challenging complications of systemic sclerosis. Rheumatology (Oxford) 48 Suppl 3:iii40-44. doi:10.1093/rheumatology/kep109

235. Bussone G, Mouthon $L$ (2011) Interstitial lung disease in systemic sclerosis. Autoimmun Rev 10 (5):248-255. doi:10.1016/j.autrev.2010.09.012

236. Mouthon L, Berezne A, Bussone G, Noel LH, Villiger PM, Guillevin L (2011) Scleroderma renal crisis: a rare but severe complication of systemic sclerosis. Clin Rev Allergy Immunol 40 (2):84-91. doi:10.1007/s12016-009-8191-5

237. Carreira PE (2004) Pulmonary hypertension in autoimmune rheumatic diseases. Autoimmun Rev 3 (4):313-320. doi:10.1016/j.autrev.2003.11.004

238. Murdaca G, Contatore M, Gulli R, Mandich P, Puppo F (2016) Genetic factors and systemic sclerosis. Autoimmun Rev. doi:10.1016/j.autrev.2016.01.016

239. Dieude P, Boileau C, Allanore $Y$ (2011) Immunogenetics of systemic sclerosis. Autoimmun Rev 10 (5):282-290. doi:10.1016/j.autrev.2010.09.017

240. Marie I, Gehanno JF, Bubenheim M, Duval-Modeste AB, Joly P, Dominique S, Bravard P, Noel D, Cailleux AF, Weber J, Lagoutte P, Benichou J, Levesque H (2014) Prospective study to evaluate the association between systemic sclerosis and occupational exposure and review of the literature. Autoimmun Rev 13 (2):151-156. doi:10.1016/j.autrev.2013.10.002

241. Bossini-Castillo L, Lopez-Isac E, Martin J (2015) Immunogenetics of systemic sclerosis: Defining heritability, functional variants and shared-autoimmunity pathways. J Autoimmun 64:53-65. doi:10.1016/j.jaut.2015.07.005

242. Wei J, Bhattacharyya S, Tourtellotte WG, Varga J (2011) Fibrosis in systemic sclerosis: emerging concepts and implications for targeted therapy. Autoimmun Rev 10 (5):267-275. doi:10.1016/j.autrev.2010.09.015

243. Cipriani P, Marrelli A, Liakouli V, Di Benedetto P, Giacomelli R (2011) Cellular players in angiogenesis during the course of systemic sclerosis. Autoimmun Rev 10 (10):641-646. doi:10.1016/j.autrev.2011.04.016

244. Liakouli V, Cipriani P, Marrelli A, Alvaro S, Ruscitti P, Giacomelli R (2011) Angiogenic cytokines and growth factors in systemic sclerosis. Autoimmun Rev 10 (10):590-594. doi:10.1016/j.autrev.2011.04.019

245. Servettaz A, Guilpain P, Goulvestre C, Chereau C, Hercend C, Nicco C, Guillevin L, Weill B, Mouthon L, Batteux F (2007) Radical oxygen species production induced by advanced oxidation protein products predicts clinical evolution and response to treatment in systemic sclerosis. Annals of the rheumatic diseases 66 (9):1202-1209. doi:10.1136/ard.2006.067504 
246. Launay D, Savale L, Berezne A, Le Pavec J, Hachulla E, Mouthon L, Sitbon O, Lambert B, Gaudric M, Jais X, Stephan F, Hatron PY, Lamblin N, Vignaux O, Cottin V, Farge D, Wallaert B, Guillevin L, Simonneau G, Mercier O, Fadel E, Dartevelle P, Humbert M, Mussot $S$, Working Group on Heart/Lung transplantation in systemic sclerosis of the French Network on Pulmonary H (2014) Lung and heart-lung transplantation for systemic sclerosis patients. A monocentric experience of 13 patients, review of the literature and position paper of a multidisciplinary Working Group. Presse Med 43 (10 Pt 2):e345-363. doi:10.1016/j.lpm.2014.01.020

247. Sobanski V, Launay D, Hachulla E, Humbert M (2016) Current Approaches to the Treatment of Systemic-Sclerosis-Associated Pulmonary Arterial Hypertension (SSc-PAH). Curr Rheumatol Rep 18 (2):10. doi:10.1007/s11926-015-0560-x

248. Elhai M, Meune C, Avouac J, Kahan A, Allanore Y (2012) Trends in mortality in patients with systemic sclerosis over 40 years: a systematic review and metaanalysis of cohort studies. Rheumatology (Oxford) 51 (6):1017-1026. doi:10.1093/rheumatology/ker269

249. Vonk MC, Marjanovic Z, van den Hoogen FH, Zohar S, Schattenberg AV, Fibbe WE, Larghero J, Gluckman E, Preijers FW, van Dijk AP, Bax JJ, Roblot P, van Riel PL, van Laar JM, Farge D (2008) Long-term follow-up results after autologous haematopoietic stem cell transplantation for severe systemic sclerosis. Annals of the rheumatic diseases 67 (1):98-104. doi:10.1136/ard.2007.071464

250. Binks M, Passweg JR, Furst D, McSweeney P, Sullivan K, Besenthal C, Finke J, Peter HH, van Laar J, Breedveld FC, Fibbe WE, Farge D, Gluckman E, Locatelli F, Martini A, van den Hoogen F, van de Putte L, Schattenberg AV, Arnold R, Bacon PA, Emery P, Espigado I, Hertenstein B, Hiepe F, Kashyap A, Kotter I, Marmont A, Martinez A, Pascual MJ, Gratwohl A, Prentice HG, Black C, Tyndall A (2001) Phase $\mathrm{I} / \mathrm{Il}$ trial of autologous stem cell transplantation in systemic sclerosis: procedure related mortality and impact on skin disease. Annals of the rheumatic diseases 60 (6):577-584

251. van Laar JM, Farge D, Sont JK, Naraghi K, Marjanovic Z, Larghero J, Schuerwegh AJ, Marijt EW, Vonk MC, Schattenberg AV, Matucci-Cerinic M, Voskuyl AE, van de Loosdrecht AA, Daikeler T, Kotter I, Schmalzing M, Martin T, Lioure B, Weiner SM, Kreuter A, Deligny C, Durand JM, Emery P, Machold KP, SarrotReynauld F, Warnatz K, Adoue DF, Constans J, Tony HP, Del Papa N, Fassas A, Himsel A, Launay D, Lo Monaco A, Philippe P, Quere I, Rich E, Westhovens R, Griffiths B, Saccardi R, van den Hoogen FH, Fibbe WE, Socie G, Gratwohl A, Tyndall A, Group EESS (2014) Autologous hematopoietic stem cell transplantation vs intravenous pulse cyclophosphamide in diffuse cutaneous systemic sclerosis: a randomized clinical trial. JAMA 311 (24):2490-2498. doi:10.1001/jama.2014.6368

252. Farge D, Marolleau JP, Zohar S, Marjanovic Z, Cabane J, Mounier N, Hachulla E, Philippe P, Sibilia J, Rabian C, Chevret S, Gluckman E, Intensification et Autogreffe dans les Maladies Auto Immunes Resistantes Study G (2002) Autologous bone marrow transplantation in the treatment of refractory systemic sclerosis: early results from a French multicentre phase I-II study. British journal of haematology 119 (3):726-739

253. Farge D, Passweg J, van Laar JM, Marjanovic Z, Besenthal C, Finke J, Peter $\mathrm{HH}$, Breedveld FC, Fibbe WE, Black C, Denton C, Koetter I, Locatelli F, Martini A, Schattenberg AV, van den Hoogen F, van de Putte L, Lanza F, Arnold R, Bacon PA, Bingham S, Ciceri F, Didier B, Diez-Martin JL, Emery P, Feremans W, Hertenstein B, Hiepe F, Luosujarvi R, Leon Lara A, Marmont A, Martinez AM, Pascual Cascon H, Bocelli-Tyndall C, Gluckman E, Gratwohl A, Tyndall A, Registry EE (2004) 
Autologous stem cell transplantation in the treatment of systemic sclerosis: report from the EBMT/EULAR Registry. Annals of the rheumatic diseases 63 (8):974-981. doi:10.1136/ard.2003.011205

254. van Laar JM, Naraghi K, Tyndall A (2015) Haematopoietic stem cell transplantation for poor-prognosis systemic sclerosis. Rheumatology 54 (12):21262133. doi:10.1093/rheumatology/kev117

255. Tyndall A (2011) Successes and failures of stem cell transplantation in autoimmune diseases. Hematology / the Education Program of the American Society of Hematology American Society of Hematology Education Program 2011:280-284. doi:10.1182/asheducation-2011.1.280

256. Tyndall A (2014) Mesenchymal stem cell treatments in rheumatology: a glass half full? Nature reviews Rheumatology 10 (2):117-124. doi:10.1038/nrrheum.2013.166

257. Larghero J, Farge D, Braccini A, Lecourt S, Scherberich A, Fois E, Verrecchia F, Daikeler T, Gluckman E, Tyndall A, Bocelli-Tyndall C (2008) Phenotypical and functional characteristics of in vitro expanded bone marrow mesenchymal stem cells from patients with systemic sclerosis. Ann Rheum Dis 67 (4):443-449. doi:10.1136/ard.2007.071233

258. Bocelli-Tyndall C, Bracci L, Spagnoli G, Braccini A, Bouchenaki M, Ceredig R, Pistoia V, Martin I, Tyndall A (2007) Bone marrow mesenchymal stromal cells (BMMSCs) from healthy donors and auto-immune disease patients reduce the proliferation of autologous- and allogeneic-stimulated lymphocytes in vitro. Rheumatology (Oxford) 46 (3):403-408. doi:10.1093/rheumatology/kel267

259. Del Papa N, Quirici N, Soligo D, Scavullo C, Cortiana M, Borsotti C, Maglione W, Comina DP, Vitali C, Fraticelli P, Gabrielli A, Cortelezzi A, Lambertenghi-Deliliers G (2006) Bone marrow endothelial progenitors are defective in systemic sclerosis. Arthritis Rheum 54 (8):2605-2615. doi:10.1002/art.22035

260. Cipriani P, Guiducci S, Miniati I, Cinelli M, Urbani S, Marrelli A, Dolo V, Pavan A, Saccardi R, Tyndall A, Giacomelli R, Cerinic MM (2007) Impairment of endothelial cell differentiation from bone marrow-derived mesenchymal stem cells: new insight into the pathogenesis of systemic sclerosis. Arthritis Rheum 56 (6):1994-2004. doi:10.1002/art.22698

261. Cipriani P, Di Benedetto P, Liakouli V, Del Papa B, Di Padova M, Di Ianni M, Marrelli A, Alesse E, Giacomelli R (2013) Mesenchymal stem cells (MSCs) from scleroderma patients (SSc) preserve their immunomodulatory properties although senescent and normally induce $T$ regulatory cells (Tregs) with a functional phenotype: implications for cellular-based therapy. Clin Exp Immunol 173 (2):195206. doi:10.1111/cei.12111

262. Guiducci S, Manetti M, Romano E, Mazzanti B, Ceccarelli C, Dal Pozzo S, Milia AF, Bellando-Randone S, Fiori G, Conforti ML, Saccardi R, lbba-Manneschi L, Matucci-Cerinic M (2011) Bone marrow-derived mesenchymal stem cells from early diffuse systemic sclerosis exhibit a paracrine machinery and stimulate angiogenesis in vitro. Ann Rheum Dis 70 (11):2011-2021. doi:10.1136/ard.2011.150607

263. Vanneaux V, Farge-Bancel D, Lecourt S, Baraut J, Cras A, Jean-Louis F, Brun C, Verrecchia F, Larghero J, Michel L (2013) Expression of transforming growth factor beta receptor II in mesenchymal stem cells from systemic sclerosis patients. BMJ Open 3 (1). doi:10.1136/bmjopen-2012-001890

264. Scuderi N, Ceccarelli S, Onesti MG, Fioramonti P, Guidi C, Romano F, Frati L, Angeloni A, Marchese C (2013) Human adipose-derived stromal cells for cell-based 
therapies in the treatment of systemic sclerosis. Cell transplantation 22 (5):779-795. doi:10.3727/096368912X639017

265. Batteux F, Kavian N, Servettaz A (2011) New insights on chemically induced animal models of systemic sclerosis. Current opinion in rheumatology 23 (6):511-518. doi:10.1097/BOR.0b013e32834b1606

266. Inamdar AC, Inamdar AA (2013) Mesenchymal stem cell therapy in lung disorders: pathogenesis of lung diseases and mechanism of action of mesenchymal stem cell. Experimental lung research 39 (8):315-327. doi:10.3109/01902148.2013.816803

267. Rojas M, Xu J, Woods CR, Mora AL, Spears W, Roman J, Brigham KL (2005) Bone marrow-derived mesenchymal stem cells in repair of the injured lung. Am J Respir Cell Mol Biol 33 (2):145-152. doi:10.1165/rcmb.2004-03300C

268. Kumamoto M, Nishiwaki T, Matsuo N, Kimura H, Matsushima K (2009) Minimally cultured bone marrow mesenchymal stem cells ameliorate fibrotic lung injury. Eur Respir J 34 (3):740-748. doi:09031936.00128508 [pii]

\subsection{3/09031936.00128508}

269. Cargnoni A, Gibelli L, Tosini A, Signoroni PB, Nassuato C, Arienti D, Lombardi G, Albertini A, Wengler GS, Parolini O (2009) Transplantation of allogeneic and xenogeneic placenta-derived cells reduces bleomycin-induced lung fibrosis. Cell transplantation 18 (4):405-422. doi:10.3727/096368909788809857

270. Ortiz LA, Dutreil M, Fattman C, Pandey AC, Torres G, Go K, Phinney DG (2007) Interleukin 1 receptor antagonist mediates the antiinflammatory and antifibrotic effect of mesenchymal stem cells during lung injury. Proceedings of the National Academy of Sciences of the United States of America 104 (26):11002-11007. doi:10.1073/pnas.0704421104

271. Lee RH, Pulin AA, Seo MJ, Kota DJ, Ylostalo J, Larson BL, Semprun-Prieto L, Delafontaine P, Prockop DJ (2009) Intravenous hMSCs improve myocardial infarction in mice because cells embolized in lung are activated to secrete the antiinflammatory protein TSG-6. Cell stem cell 5 (1):54-63. doi:10.1016/j.stem.2009.05.003

272. Lee SH, Jang AS, Kim YE, Cha JY, Kim TH, Jung S, Park SK, Lee YK, Won JH, Kim YH, Park CS (2010) Modulation of cytokine and nitric oxide by mesenchymal stem cell transfer in lung injury/fibrosis. Respiratory research 11:16. doi:10.1186/1465-9921-11-16

273. Conese M, Carbone A, Castellani S, Di Gioia S (2013) Paracrine effects and heterogeneity of marrow-derived stem/progenitor cells: relevance for the treatment of respiratory diseases. Cells, tissues, organs 197 (6):445-473. doi:10.1159/000348831

274. Servettaz A, Goulvestre C, Kavian N, Nicco C, Guilpain P, Chereau C, Vuiblet V, Guillevin L, Mouthon L, Weill B, Batteux F (2009) Selective oxidation of DNA topoisomerase 1 induces systemic sclerosis in the mouse. Journal of immunology 182 (9):5855-5864. doi:10.4049/jimmunol.0803705

275. Hua-Huy T, Le-Dong NN, Duong-Quy S, Bei Y, Riviere S, Tiev KP, Nicco C, Chereau C, Batteux F, Dinh-Xuan AT (2015) Increased exhaled nitric oxide precedes lung fibrosis in two murine models of systemic sclerosis. J Breath Res 9 (3):036007. doi:10.1088/1752-7155/9/3/036007

276. Kavian N, Marut W, Servettaz A, Nicco C, Chereau C, Lemarechal H, Borderie D, Dupin N, Weill B, Batteux F (2012) Reactive oxygen species-mediated killing of activated fibroblasts by arsenic trioxide ameliorates fibrosis in a murine model of systemic sclerosis. Arthritis and rheumatism 64 (10):3430-3440. doi:10.1002/art.34534 
277. Kavian N, Servettaz A, Marut W, Nicco C, Chereau C, Weill B, Batteux F (2012) Sunitinib inhibits the phosphorylation of platelet-derived growth factor receptor beta in the skin of mice with scleroderma-like features and prevents the development of the disease. Arthritis and rheumatism 64 (6):1990-2000. doi:10.1002/art.34354

278. Kavian N, Servettaz A, Mongaret C, Wang A, Nicco C, Chereau C, Grange P, Vuiblet V, Birembaut P, Diebold MD, Weill B, Dupin N, Batteux F (2010) Targeting ADAM-17/notch signaling abrogates the development of systemic sclerosis in a murine model. Arthritis and rheumatism 62 (11):3477-3487. doi:10.1002/art.27626

279. Marut W, Jamier V, Kavian N, Servettaz A, Winyard PG, Eggleton P, Anwar A, Nicco C, Jacob C, Chereau C, Weill B, Batteux F (2013) The natural organosulfur compound dipropyltetrasulfide prevents $\mathrm{HOCl}$-induced systemic sclerosis in the mouse. Arthritis research \& therapy 15 (5):R167. doi:10.1186/ar4351

280. Marut W, Kavian N, Servettaz A, Hua-Huy T, Nicco C, Chereau C, Weill B, Dinh-Xuan AT, Batteux F (2013) Amelioration of systemic fibrosis in mice by angiotensin II receptor blockade. Arthritis and rheumatism 65 (5):1367-1377. doi:10.1002/art.37873

281. Marut WK, Kavian N, Servettaz A, Nicco C, Ba LA, Doering M, Chereau C, Jacob C, Weill B, Batteux F (2012) The organotelluride catalyst (PHTE)(2)NQ prevents $\mathrm{HOCl}$-induced systemic sclerosis in mouse. The Journal of investigative dermatology 132 (4):1125-1132. doi:10.1038/jid.2011.455

282. Servettaz A, Kavian N, Nicco C, Deveaux V, Chereau C, Wang A, Zimmer A, Lotersztajn S, Weill B, Batteux F (2010) Targeting the cannabinoid pathway limits the development of fibrosis and autoimmunity in a mouse model of systemic sclerosis. Am J Pathol 177 (1):187-196. doi:10.2353/ajpath.2010.090763

283. Bagnato G, Bitto A, Irrera N, Pizzino G, Sangari D, Cinquegrani M, Roberts W, Atteritano M, Altavilla D, Squadrito F, Bagnato G, Saitta A (2013) Propylthiouracil prevents cutaneous and pulmonary fibrosis in the reactive oxygen species murine model of systemic sclerosis. Arthritis research \& therapy 15 (5):R120. doi:10.1186/ar4300

284. Bagnato G, Bitto A, Pizzino G, Irrera N, Sangari D, Cinquegrani M, Roberts WN, Matucci Cerinic M, Squadrito F, Altavilla D, Bagnato G, Saitta A (2013) Simvastatin attenuates the development of pulmonary and cutaneous fibrosis in a murine model $\begin{array}{llll}\text { of systemic sclerosis. } & \text { Rheumatology } 52 & \text { (8):1377-1386. }\end{array}$ doi:10.1093/rheumatology/ket144

285. Naderi N, Combellack EJ, Griffin M, Sedaghati T, Javed M, Findlay MW, Wallace CG, Mosahebi A, Butler PE, Seifalian AM, Whitaker IS (2016) The regenerative role of adipose-derived stem cells (ADSC) in plastic and reconstructive surgery. Int Wound J. doi:10.1111/iwj.12569

286. Lataillade JJ, Doucet C, Bey E, Carsin H, Huet C, Clairand I, Bottollier-Depois JF, Chapel A, Ernou I, Gourven M, Boutin L, Hayden A, Carcamo C, Buglova E, Joussemet M, de Revel T, Gourmelon P (2007) New approach to radiation burn treatment by dosimetry-guided surgery combined with autologous mesenchymal stem cell therapy. Regen Med 2 (5):785-794. doi:10.2217/17460751.2.5.785

287. Bey E, Prat M, Duhamel P, Benderitter M, Brachet M, Trompier F, Battaglini $P$, Ernou I, Boutin L, Gourven M, Tissedre F, Crea S, Mansour CA, de Revel T, Carsin H, Gourmelon P, Lataillade JJ (2010) Emerging therapy for improving wound repair of severe radiation burns using local bone marrow-derived stem cell administrations. Wound Repair Regen 18 (1):50-58. doi:10.1111/j.1524-475X.2009.00562.x 
288. Leclerc T, Thepenier C, Jault P, Bey E, Peltzer J, Trouillas M, Duhamel P, Bargues L, Prat M, Bonderriter M, Lataillade JJ (2011) Cell therapy of burns. Cell Prolif 44 Suppl 1:48-54. doi:10.1111/j.1365-2184.2010.00727.x

289. Linard C, Busson E, Holler V, Strup-Perrot C, Lacave-Lapalun JV, Lhomme B, Prat M, Devauchelle P, Sabourin JC, Simon JM, Bonneau M, Lataillade JJ, Benderitter M (2013) Repeated autologous bone marrow-derived mesenchymal stem cell injections improve radiation-induced proctitis in pigs. Stem Cells Transl Med 2 (11):916-927. doi:10.5966/sctm.2013-0030

290. Linard C, Tissedre F, Busson E, Holler V, Leclerc T, Strup-Perrot C, Couty L, L'Homme B, Benderitter M, Lafont A, Lataillade JJ, Coulomb B (2015) Therapeutic potential of gingival fibroblasts for cutaneous radiation syndrome: comparison to bone marrow-mesenchymal stem cell grafts. Stem Cells Dev 24 (10):1182-1193. doi:10.1089/scd.2014.0486

291. Christopeit M, Schendel M, Foll J, Muller LP, Keysser G, Behre G (2008) Marked improvement of severe progressive systemic sclerosis after transplantation of mesenchymal stem cells from an allogeneic haploidentical-related donor mediated by ligation of CD137L. Leukemia 22 (5):1062-1064. doi:10.1038/sj.leu.2404996 292. Keyszer G, Christopeit M, Fick S, Schendel M, Taute BM, Behre G, Muller LP, Schmoll HJ (2011) Treatment of severe progressive systemic sclerosis with transplantation of mesenchymal stromal cells from allogeneic related donors: report of five cases. Arthritis and rheumatism 63 (8):2540-2542. doi:10.1002/art.30431

293. Guiducci S, Porta F, Saccardi R, Guidi S, Ibba-Manneschi L, Manetti M, Mazzanti B, Dal Pozzo S, Milia AF, Bellando-Randone S, Miniati I, Fiori G, Fontana R, Amanzi L, Braschi F, Bosi A, Matucci-Cerinic M (2010) Autologous mesenchymal stem cells foster revascularization of ischemic limbs in systemic sclerosis: a case report. Annals of internal medicine 153 (10):650-654. doi:10.7326/0003-4819-153-10201011160-00007

294. Granel B, Daumas A, Jouve E, Harle JR, Nguyen PS, Chabannon C, Colavolpe N, Reynier JC, Truillet R, Mallet S, Baiada A, Casanova D, Giraudo L, Arnaud L, Veran J, Sabatier F, Magalon G (2015) Safety, tolerability and potential efficacy of injection of autologous adipose-derived stromal vascular fraction in the fingers of patients with systemic sclerosis: an open-label phase I trial. Annals of the rheumatic diseases 74 (12):2175-2182. doi:10.1136/annrheumdis-2014-205681 


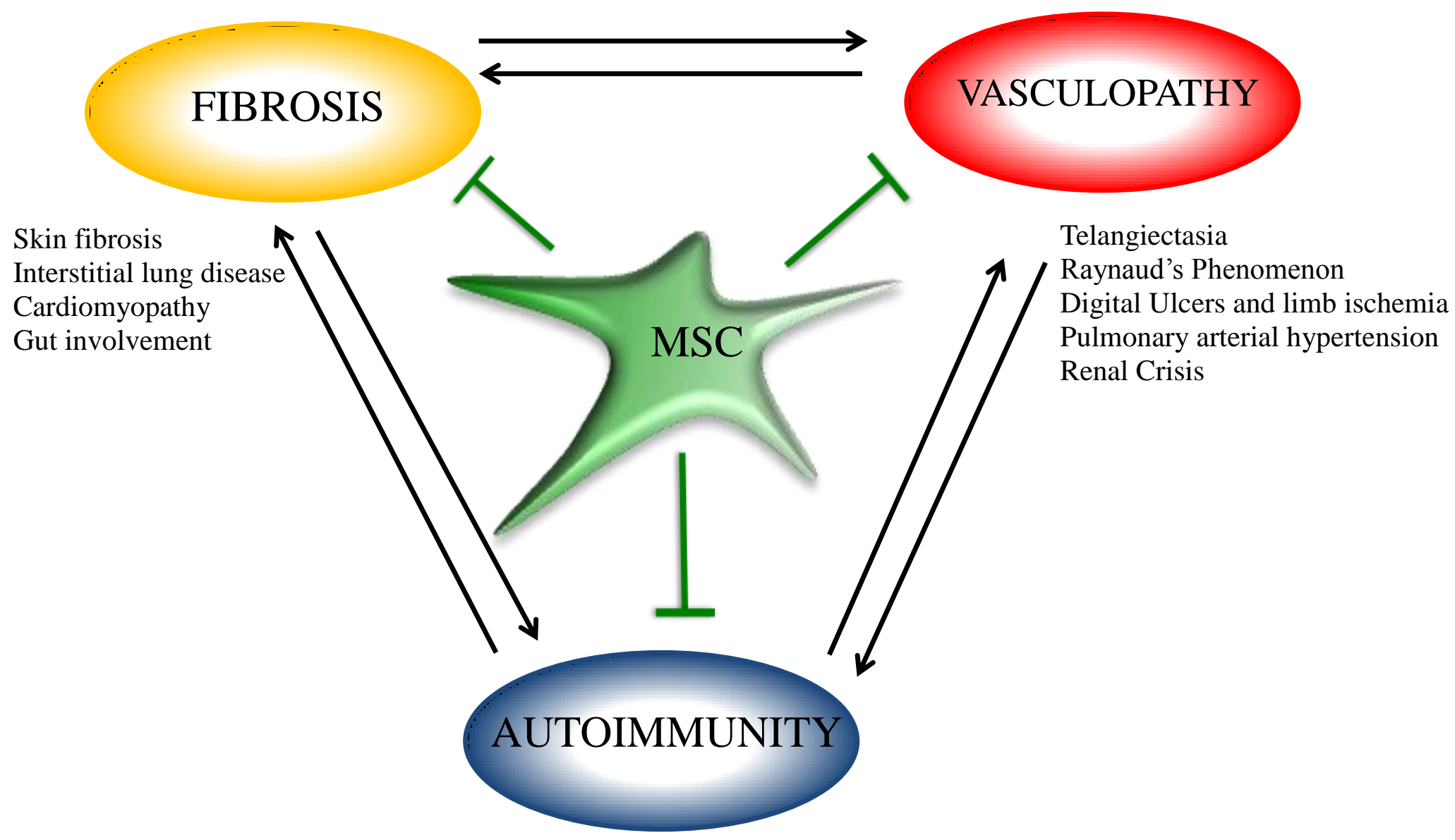

Autoantibodies against:

Topo-isomerase 1 (scl-70)

Centromere (CENPB)

RNA Polymerase III

Figure: Mesenchymal stem cells, towards a global approach of systemic sclerosis 